\title{
A Qualitative Examination of Middle Grade Practices in Christian Schools: Could They Become Models for Middle Level Reform?
}

Teresea Baumann

Cedarville University

Follow this and additional works at: http://digitalcommons.cedarville.edu/education theses

Part of the Junior High, Intermediate, Middle School Education and Teaching Commons

\section{Recommended Citation}

Baumann, Teresea, "A Qualitative Examination of Middle Grade Practices in Christian Schools: Could They Become Models for Middle Level Reform?" (2005). Master of Education Research Theses. 7.

http://digitalcommons.cedarville.edu/education_theses/7 
A QUALITATITVE EXAMINATION OF MIDDLE GRADE PRACTICES IN CHRISTIAN SCHOOLS: COULD THEY BECOME MODELS FOR MIDDLE LEVEL REFORM?

A thesis submitted in partial fulfillment of the requirements for the degree of

Masters of Education

By

TERESEA LYNNE BAUMANN

B.S., Grace College, 1982

2005

Cedarville University 


\section{CEDARVILLE UNIVERSITY \\ SCHOOL OF GRADUATE STUDIES}

May 7, 2005

I HEREBY RECOMMEND THAT THE THESIS PREPARED UNDER MY

SUPERVISION BY Teresea Lynne Baumann ENTITLED A Qualitative Examination of Middle Grade Practices in Christian Schools: Could They Become Models for Middle Reform? BE ACCEPTED IN PARTIAL FULFILLMENT OF THE REQUIREMENTS FOR THE DEGREE OF Master of Education.

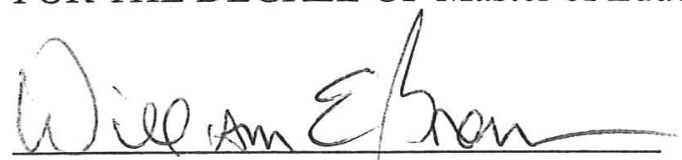

William E. Brown, Ph.D.

President

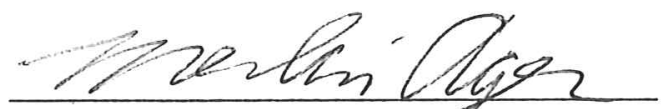

Merlin Ager, Ph.D.

Dean, School of Social Sciences

And Professional Studies hemane R. Worde Duane R. Wood, D.B.A. Academic Vice President

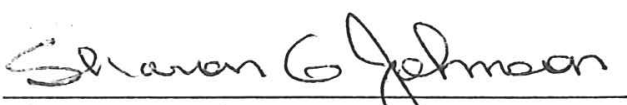

Sharon G. Johnson, D.B.A.

Director of Graduate Programs

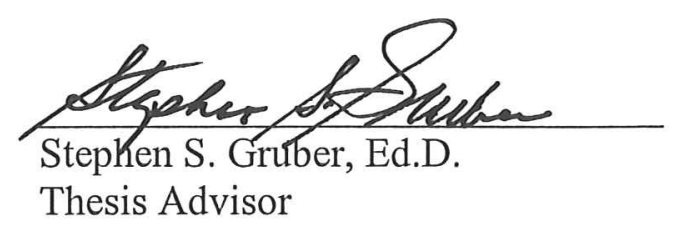




\begin{abstract}
Baumann, Teresea Lynne, M.Ed. Education Department, Cedarville University, 2005. A qualitative examination of middle grades practices in Christian schools: Could they be models for middle level reform?

There has been much debate concerning the educational structures best suited for the teaching of students during the pivotal years from ages ten to fifteen. Many researchers and educators believe that the educational experiences for this age group need to be tailored to the unique qualities of this time in the life of a student. One purpose of this thesis is to examine the best practices for educating children during this time period. Another purpose of the study is to compare and contrast the practices in private Christian day schools to similar studies done of public school settings. The study found that although Christian schools are strong in areas like dedicated teachers, communication with parents, and ease of transition to the middle grades, they are not strong in things like teaming, heterogeneous grouping, and being task oriented.
\end{abstract}




\section{TABLE OF CONTENTS}

Page

CHAPTER I: Introduction..................................................

Educational Significance..............................................1

Purpose of the Study................................................4

Research Methodology...............................................6

Biblical Integration..................................................

Application to Current School.........................................9

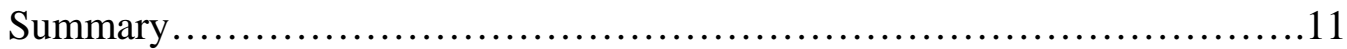

CHAPTER II: Literature Review............................................12

The Developmental Period of Adolescence.................................12

Models for Educational Structures at the Mid-Level.........................17

Teaming.......................................................

Heterogeneous Grouping.........................................19

Student-Centered...............................................20

Curriculum....................................................21

Motivational Drop...........................................22

Teachers........................................................23

Criticism of the Middle School Movement...................................25

The Development of the Christian Day School............................29

Christian School Structures..............................................35

CHAPTER III: Procedures and Results.........................................

Research Procedures.....................................................37 


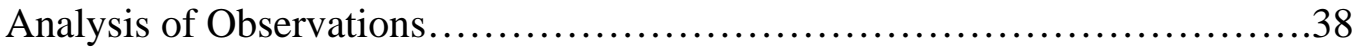

Administrative Survey Data...................................................44

Teacher Certification.....................................................44

Plan for Transition to the Middle Grades.......................................45

Teacher Interview Data................................................46

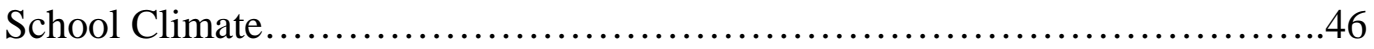

Styles of Classrooms...................................................47

Discipline Styles..........................................................48

School Structures........................................................49

CHAPTER IV: Conclusions and Recommendations................................53

Conclusions from the Literature Review.......................................53

Christian School Structures..............................................55

Patterns Found in the Eighteen Schools Studied...............................56

Implications for Christian Schools........................................58

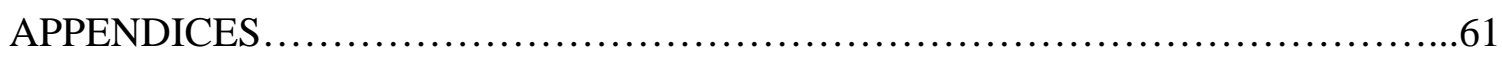

APPENDIX A: Checklist of Middle School Practices...........................61

APPENDIX B: General Directions for the Data Gathering....................63

APPENDIX C: Administrative Letter........................................64

APPENDIX D: Administrative Survey......................................65

APPENDIX E: Research Procedures for Shadowing a Teacher or Student......67

APPENDIX F: Observation Form..........................................68

APPENDIX G: Permission Slip...........................................69

APPENDIX H: Teacher Interview........................................70 
APPENDIX I: Student Interview....

APPENDIX J: End of the Day Research Reflections......................72

APPENDIX K: Chart of Activities Observed..............................73

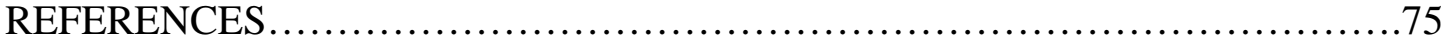

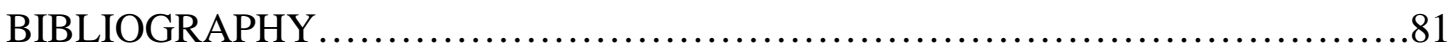

VITA...................................................................... 85 


\section{ACKNOWLEDGEMENTS}

There are many people that were a help and encouragement as I pursued my graduate degree. I am deeply grateful for their support during this process.

First of all, I would like to thank all of the professors in the graduate program at Cedarville University. You were wonderful and helpful. Many of you I knew from outside of the classroom. It was fun and interesting getting to know you as a professor.

Dr. Eddie Baumann, thank you for very carefully taking the role as my professor while also being my husband. I know that there were times when I tried your patience. You are a great husband and a great professor. Thanks for helping me to broaden my view of education.

Dr. Stephen Gruber, thank you for your tireless work on developing the graduate programs. Thank you for helping me through the process of writing my thesis.

Dr. Phillip Bassett, thank you for being a friend as well as an excellent professor. Thank you for the excellent start in the program when I took your Models of Teaching class. It was fun, active, and had a great impact on my style of teaching.

Dayton Christian Schools, thank you fro having the vision for graduate degrees for your teachers and then thank you for funding that vision with financial help to complete this degree.

Patricia Dunstan, my principal, thank you for your patience and understanding as I worked on this degree. Your support was great when I was going through those stressed out times of meeting deadlines, etc.

To the Cedarville students who gathered data for me, thank you so much for your help. I literally could not have gathered my data and written my thesis without your help.

To my children, Abby and Jonathan, thank you for your patience while I worked on my graduate degree. Thank you for sharing the computer so that I could write. Thank you for being patient with all of the times that we could not go do fun things because I needed to work on my graduate assignments. 


\section{DEDICATION}

I am dedicating this to my husband and professor, Dr. Eddie Baumann. When the program first started in 2000, you encouraged me to take a class. Then as I decided to pursue the complete degree, you supported me by helping with the children, helping me around the house, and by being my sounding board when I needed someone to hear my ideas. Your dedication to your relationship with Christ, your leadership in our family, and your desire to be excellent as an educator are an inspiration to me. 


\section{CHAPTER I. INTRODUCTION}

\section{Educational Significance}

Since the development of public high schools in the early 1900's, there have been differing ideas about how to structure education for students in early adolescence. Much research has been done to confirm that adolescents ranging from age 10-15 are in a very difficult time period in their lives. They are changing physically, socially, and mentally. These changes are complicated by the fact that each individual adolescent is going through these changes at his or her own irregular rate (Knowles and Brown, p.4). The challenge of handling students dealing with these changes at varying rates has caused educators much difficulty throughout the history of education. Often, students of this age have been lost in the transition between elementary school and high school.

Traditionally, there have been several approaches to dealing with students in grades 5-8. One approach has been to keep them in a more elementary setting in K-8 schools. Another approach has been to have junior high schools in which grades 7-9 are placed in separate settings that are very much like high school in which they go through 45 minute periods with different teachers and students in each class. Finally, a more recent approach has been the development of a middle school model. In a middle school model, students are grouped together in teams and tend to move through the day together through blocks of time with fewer teachers (Williamson and Johnston, 1999, p.9).

Much research has been done to document a drop in achievement during the time of early adolescence. Motivation for learning also seems to drop at this time. Many times it is assumed that this drop is mostly due to physiological and psychological 
changes that occur due to the onset of puberty. However, educational researchers such as Anderman \& Midgley have challenged this notion by studying the effect of school structure changes on adolescent achievement and motivation. They have found that these drops are due at least partly to the kind of school structure being faced by the adolescent (1998).

Another factor in the education of early adolescents is the drop in parent involvement. Williamson and Johnson found that during the elementary grades, parents volunteer more and seem to know more of what is going on in the life of their children while they are at school. When students reach middle school or junior high, they are often in larger schools and have six or seven different teachers throughout the course of the day. Parents have a harder time keeping involved and appreciating the education that is occurring for their children. All of this happens at a time when the children themselves are acting like they want less involvement from their parents (Williamson \& Johnston, 1999, p. 5). Developing the kind of schools that are more effective at keeping parents involved through middle school is important.

Due to the many unique factors of this time period in the life of a student, much research and effort has been made to reform the education of students in grades 58. The Carnegie Council on Adolescent Development published a classic report called Turning Points (1989). In this report the authors called for the formation of middle schools that are responsive to the unique needs of early adolescence. These schools would differ greatly from high schools. They would need to have smaller groupings within larger school settings. The schedule would need to be more flexible with the possibility of having longer blocks of time for more cooperative and open-ended learning 
opportunities. The curriculum would need to be more appropriate to the everyday lives of the students. The teachers would teach more than one subject and be given freedom to develop curriculum plans with the students. These teachers would be specially trained to deal with students in this stage of life.

This report and much other research in this area caused the state of Ohio, as well as other states, to change licensure of teachers from either a K-8 or 9-12 certificate to now having teachers certified to specifically deal with students in grades 4- 8. These teachers are being certified in at least two areas of curriculum so that they will be able to teach more than one subject. As this difference in teacher training trickles down to schools, it is important that administrators be able to take advantage of hiring teachers that are experts in dealing with middle school children. It will be difficult to fully use these teachers if the model for dealing with middle school children is unclear or if it is kept strictly traditional (Brockett, 1999, p.2).

Middle school models became popular at about the same time that many Christian parents became displeased with public education. As a result of this displeasure, many churches and parent groups began forming their own private Christian schools. Much of this movement was driven by a desire to return to the traditional days of education. The parents were unhappy with the teaching of evolution in the classroom and the removal of prayer or any references to God. As a result of the reaction, most Christian schools follow the more traditional methods of education.

The Christian school movement often reproduced schools that were much like their public counterparts in their structuring of educational procedures. In the early days of the movement, many of the schools were quite small and included only the lower 
elementary grades. As the movement grew, grades were gradually added to schools until they eventually reached high school. Because they were small, grades 7-12 would usually share the same set of high school teachers while grades K-6 were usually kept in self-contained classrooms. As the size of some of the schools grew, eventually students in grades 6-8 were separated at least for administrative purposes.

In recent years, the middle school reform movement has come under criticism. Some claim that it focuses too much on developmental issues and not enough on academic preparation. According to Weilbacher, state mandated tests have caused interdisciplinary teaching and student-centered curriculum to take a backseat to preparation of students to pass state proficiency tests (Weilbacher, 2000, p.20). During this time when it is becoming difficult to use all of the elements of the middle school model in public school, it would be of interest to see what is happening in private Christian schools that are not as strongly tied to state mandates on curriculum.

A closer look at the advantages and disadvantages of the middle school reform movement is needed. The research supports the need to design special procedures and settings for this unique period of development in education. Christian schools have the freedom to continue to educate middle school students in a way that best suits their needs.

\section{Purpose of the Study}

The purpose of this study will include several components. First of all, it will include a best evidence synthesis (Slavin, 1986, p. 6) of what the research seems to be saying is the best way to educate students in the middle grades. The second component will be an analysis of the history of the Christian school movement and how most 
Christian schools have traditionally handled the education of middle school students. The third component will be a study of the current practices of a cross-section of Christian schools in the area of mid-level education. Finally, this study will analyze the components of progressive middle school reform and find which aspects Christian schools are already doing well and which aspects of the reform could be improved or implemented in Christian schools.

The emphasis of this study will be to look at whether Christian schools are doing more than just referring to grades 6-8 as middle school in name only, but that they are attempting to adjust the philosophical approach of the teaching these grades to focus on the specific developmental issues for the learners in this time period (Knowles, 2000, p.47-8).

The researcher will be looking at Christian school treatment of grades 5-8. The key elements that will be evaluated include the following factors that define a middle school according to the research. It includes small learning teams, a core academic program, elimination of tracking, giving teachers and administrators creative control of planning experiences, finding staff that is qualified to teach in more than one subject area, developing a staff that is expert at dealing with middle school students, allowing time for focus on health and fitness issues, engaging families in the education of their middle school students, and connecting the school to the community (Knowles, 2000, p.49-50).

The researcher will be examining the components of a true middle school model and analyzing whether the educational benefits of this approach would justify any restructuring of the ways most Christian schools currently handle middle school students. 
It will also study the explicit and implicit philosophy of Christian education to see if the middle school model is a good fit with its philosophy.

\section{Research Methodology}

The research methods for this project will be an in depth study of the current literature on the most effective school structures for the education of the mid-level grades. This literature will be analyzed and compared to the current practices of most Christian schools. Attention will also be given to the underlying philosophy of the Christian education movement. The researcher will be looking for areas in which the middle school model makes sense for Christian schools, and where it does not fall in line with their current philosophy.

In order to understand what is currently being practiced in many Christian schools, the researcher has designed a shadow study of 18 Christian schools across the country. The shadow study will be accomplished using Cedarville University student. At Cedarville all education majors are required to spend a week observing teachers and students in a Christian school setting. The university students must do this during one of their breaks from classes and are allowed to choose the most conveniently located school during their break for the observation. The researchers will perform an interval observation every 5 to 7 minutes throughout one day in which they record the types of activities taking place in the classrooms they are observing. They will also be asked to interview administrators and teachers at these schools about their mid-level grades educational practices. Finally, these students will be asked to fill out a survey of their reactions to the things that they observed in these classrooms. 
The researcher will take the data collected by the university students and analyze it carefully, looking for trends and patterns in the practices of Christian schools and their treatment of mid-level education. This will be a qualitative study to examine what components of the middle school model already seem to be in place and what components are missing.

\section{Biblical Integration}

The importance of appropriate education is stated and implied throughout the Bible. Beginning in Genesis 1:28 and again in Genesis 3:15, God directs that man subdue creation. MacArthur (1997) in his study notes, states that this means that man is to productively order the things on earth. Man is to create culture and an important part of culture is education.

In the Old Testament, great emphasis is placed on the role of the parent. It was the responsibility of the parent to see that the knowledge of God was passed from generation to generation. In Deuteronomy 6:6-8, Jewish parents were given the following command:

"And these words which I command you today shall be in your heart. You shall teach them diligently to your children, and shall talk of them when you sit in your house, when you walk by the way, when you lie down, and when you rise up. You shall bind them as a sign on your hand, and they shall be as frontlets between your eyes. You shall write them on the doorposts of your house and on your gates.

Similar commands are given in Deuteronomy 4: 5, 9, 10. The responsibility of developing the worldview and philosophy of the next generation was in the hands of the parents. 
Another interesting idea that comes from references to training of children is that various stages in a child's life were handled differently. Scripture indicates that all Jewish children in their early years from infancy to age five were trained by their mothers. Proverbs 31:1 states that King Lemuel was uttering the wisdom taught to him by his mother. II Timothy 1:5 and 3:15 give testimony to the importance of the early training that Timothy received from his grandmother and mother. At age five Jewish boys were trained by their fathers or if they were wealthy, they were trained by a tutor. Galatians 3:24 , I Samuel 10:12, and II Kings 10:1,5 talk of this change in training. Finally, at age twelve for girls and age thirteen for boys, Jewish children go through Bat Mitvah for girls or Bar Mitvah for boys. This is a special coming of age ceremony in which the responsibility for the child's deeds pass from the parents to the individual child. In light of studying practices for teaching middle childhood students, it is interesting to note that Jewish tradition realized the importance of the entrance from childhood to adulthood that begins at age twelve or thirteen. It is even interesting that the tradition has girls going through this ceremony earlier than boys. This seems to be especially in line with the different maturation rates between girls and boys at this age documented by educational psychology.

The best examples for education and teaching in the New Testament come from the teaching style of Jesus himself. It is interesting that Jesus used many of the methods and structures for his teaching style that research today finds effective. Jesus sometimes used the lecture style in his teaching. Matthew 5 and 6 are the record of Jesus' famous Sermon on the Mount. Other times in the gospels Jesus taught using parables to powerfully illustrate the points he was trying to teach. Matthew 13:1-3 talks of him using 
this style of teaching. Other places in the gospels, Jesus used discussions to interact with the people around him and to hold their attention. Sometimes Jesus used modeling to teach a skill such as when he was demonstrating to the disciples about how to pray. In Matthew 6:8-14, he begins his giving of the Lord's Prayer by saying when you pray, pray like this. Jesus also often used object lessons to emphasize his point. In the story of the woman at the well in John 4, Jesus took a familiar object in the woman's life, her need for water from the well, and he used it to make her see her need in her spiritual life for a Savior. Finally, Jesus used hands on experiences for his disciples when he felt they were ready to minister on their own. Matthew 10:5-15 and Luke 9:2-6 tell about how Jesus sent the disciples out to minister to surrounding towns and villages. Jesus clearly used many varied effective teaching strategies during his earthly ministry.

In the Bible in Colossian 3:17 all Christians are called to be excellent at what they do and say. According to Schindler, former superintendent of Dayton Christian Schools, in his book Sowing for Excellence, the Christian school should be an extension of the family and of the church. In this role the school has a responsibility to do whatever it can to provide all students with an excellent education. One goal of Christian education is to train students to think and function with a Christian worldview. Dealing with middle school students is often challenging because they are not afraid to ask difficult questions. What better time to develop a model that harnesses the energy and innate curiosity of students of this age?

\section{Application to current school}


A difficult thing for conservative evangelical Christians to do is to separate what is truly biblical and what is cultural tradition. In conservative circles, there is a lot of emphasis on the basics and core curriculum. The issue of curriculum and control of what is taught will be a very difficult issue for the administration of most typical Christian schools. The intent of this researcher will be to look closely at current practices in Christian schools and analyze how they fit with a middle school model. If some aspects of the current practices do not fit with a middle school model, are those aspects truly biblical and therefore not likely to be changed or are they cultural traditions that could be changed?

Much of the Christian philosophy of education is centered on developing positive character qualities in each of the students. There is also a strong emphasis on integrating God's word throughout the curriculum (Schindler, 1987, p. 157). Attempts to integrate the Bible should go hand in hand with attempts to integrate all areas of the curriculum. God has placed man in the position of being a wise steward over all of creation. Middle school seems like an excellent opportunity to begin to give students hands on experience with this stewardship in all areas.

The researcher is currently a teacher in a large Christian school that was one of the early pioneers in the Christian school movement. Currently, the school treats grades 7 and 8 like high school and grades 5 and 6 like elementary school. In grades 7 and 8 very little of the middle school model is evident. The content of this report could be helpful as the school is in the process of restructuring the treatment of grades 5-8.

It will also be important to consider restructuring practices there so that as newly certified teachers for the middle grades become available to be hired, they will be able to 
fully use the preparation that they have been given for this level of teaching. It will be difficult to attract and keep these new graduates if they are faced with strictly a traditional treatment of these grades.

\section{Summary}

In studying the research it becomes clear that the education of students during the middle level grades is a unique time period in their development and calls for special structures and strategies to be designed and used by educators. Christian schools desire to provide excellent educational opportunities for all of their students. Christian schools are also free from state mandated curriculum and pressure to pass state tests. Christian schools have an opportunity to be on the cutting edge of shaping programs that are developmentally appropriate for this age level. This study will try to understand what Christian schools are already doing and what they could be doing better to achieve excellence in this area. 


\section{CHAPTER II. LITERATURE REVIEW}

\section{The Developmental Period of Adolescence}

Developmentally, the period of early adolescence is one that many parents and educators often face with fear and trepidation. Students in this time period go from being sweet, naïve children to worldly, sarcastic teenagers who are often quite difficult to deal with at home and at school. In the past, this period was characterized as a phase that was part of the necessary evils of growing up. Much of the difficulty was blamed on hormones, self-esteem, and rebellion. Often the period was viewed as a time simply to be endured. However, since the late 60's into the early 70’s, educators and developmental psychologists have attempted to study and understand the unique qualities of this developmental time in the lives of children.

Many names are used to refer to this time period. Sometimes it is referred to as transescence because humans of this age are in a transitional period. This term was first used by Donald Eichhorn, who was a pioneer in reform for middle level education. It is often the favorite term for educational researchers focusing on this level (George \&Alexander, 1993). Other times this period is referred to as early adolescence or preadolescence. Informally, children of this age are just referred to as middle schoolers or junior highers. For the purpose of this paper this period will be referred to as middle childhood. This period stretches from ages 10-14. Often, children go through puberty during this time period. Children of this age are going through similar physical, mental, social, and emotional stages, but they go through these stages at their own pace (Schurr, 1992). 
One area of immense variation is in physical development. Knowles and Brown (2000) note that during this time period, the body has its major growth spurt. This obvious physical change is probably one of the most visible and dramatic factors of this period. Girls tend to grow around seven inches during this time period while boys will probably grow around nine or ten inches. This growth occurs with rapid and uneven skeletal changes. Often youths of this age appear lanky and graceless because their legs grow more rapidly than the rest of their skeletal frame. These changes are complicated by the fact that every adolescent goes through these dramatic changes on his or her own individual time table. (Lounsbury \& Johnson, 1988) Not only is the body growing taller, it is also maturing sexually, again on a timetable that varies from individual to individual. These individual differences in rate of change cause early adolescents to spend much time focusing on their body's changes and worrying that they are not normal (Knowles \& Brown, 2000).

Knowles and Brown (2000) also note that along with the physical changes also come the mental or intellectual changes. At the beginning of early adolescence most individuals are concrete thinkers, however during this time some begin to think and reason at a higher level. Others continue to be very concrete in their thinking processes. This leads to the irony of dealing with middle school students. Often their behavior and thinking shifts rapidly between being very adult-like in one moment and very child-like in the next moment. According to Atwell (1998), they often look old enough to be treated like adults and they demand to be given their independence while at the same time they act child-like and demand constant attention. Also because of the self-absorption over physical changes, they become very ego-centric in their thinking patterns. They 
tend to think that if they are thinking about something then everyone else must also be thinking about it. This leads to the development of an imaginary audience where they think that everyone is watching and judging everything about them (Walley \& Gerrick, 1999), (Knowles \& Brown, 2000).

According to Knowles \& Brown, the self-absorption of this stage continues in their social development. During this stage they begin to realize that some students are popular and others are not. They start trying to figure out what they must do and how they must act in order to be liked by others. Making decisions about which students they will be friends with is one of the first real choices that they will be given the opportunity to make. This often leads to experimentation with how they behave and think in order to try to identify where they fit in (2000). Shoffner and Williamson found that during this time, transescents shift from reliance on parents to reliance on peers and other non-family adults. This usually results in adolescents being much more focused on social needs than they are on academic needs (Shoffner \& Williamson, 2000). Adolescents during this time period, according to Lounsberry and Johnson (1988), begin to see significant adults in their life as fallible. They begin to realize that these adults make mistakes. They also realize that adults do not have complete control over them and can be defied.

As adolescents begin to see the fallibility of adults, they also are developing morally. Kohlberg (1981) proposed that individuals go through developmental stages much like Piaget's stages for intellectual development. They are the following:

Level One: Preconventional

Stage 1 Punishment and Obedience: literal obedience to avoid punishment Stage 2 Individual Instrumental Purpose and Exchange: serving one's own or other's needs for personal benefit

Level Two: Conventional

Stage 3 Mutual Interpersonal Expectations, Relationships, and 
Conformity: the

desire to please others and conform to perceived norms of "right" and "wrong."

Stage 4 Social System and Conscience Maintenance: doing one’s duty to preserve social order

Level Three: Postconventional and Principled

Stage 5 Prior Rights and Social Contract: commitment to relative social order; rules may change if needed.

Stage 6 Universal Ethical Principles: action determined by conscience, based on lf-chosen ethical principles.

Most educators at this level find students developing through the first four stages. Early adolescents are especially ready to learn about group citizenship. In fact, Kohlberg, George, and Alexander believe that this is a pivotal time in moral development. They believe that if students do not reach stage three by the end of the middle school years, they might never reach it. This development of adolescents morally has significance for how educators structure school and how teachers handle moral discussions (George \& Alexander, 1993). Students of this level do have morals, but they often need help making sense of them while they are in this confusing transitional period of their lives (Wallley \& Gerrick, 1999).

Many studies have been done to document a drop in motivation for learning and a drop in academic achievement during the mid-level years (Mullins \& Irvin, 2000). This seems to be especially true during major transitions from one type of school structure such as elementary school to larger school structures such as middle schools, junior highs, or high schools. Students often go from attending small schools that are located in their own neighborhoods to being bussed to larger schools that are further from their home. Researchers Williams and McGillicuddy (2000) from Lafayette College in Pennsylvania studied students coping strategies in early, middle, and late adolescents to understand how those strategies change and develop. Younger adolescents seem 
particularly vulnerable to the stress caused by major transitions because they have not developed the coping strategies to help them handle the stress (p. 545). They found that older adolescents were better equipped to handle stress because they were better at using problem solving strategies to find ways to alleviate their stress (p.546).

Knowles and Brown point out that due to the stress of changes in schools and changes physically, despite good or bad home background, behavioral issues during this time period are especially tricky. One never knows quite what to expect. Because adolescents are in a search for identity, their behavior can change from situation to situation. One moment they can be kind and compassionate, and the next moment they can be cruel and without mercy. Usually they are making attempts to gain control of their constantly changing world. Sometimes they are acting certain ways to try to protect themselves (2000).

All the tricky bends and turns in adolescent development call for educators to develop schools and teachers that are sensitive to all of these factors. The middle school movement developed out of a need to address the unique qualities of the students being educated during this time period. The desire to know how to best help students at this age is at the heart of this movement. Turning Points the Carnegie Council on Adolescent Development (1989, p.20) states the importance of a strong understanding of this time period in the following quote:

Young adolescents today make fateful choices, fateful for them and for our nation! The period of life from ages 10 to 15 represents for many young people their last best chance to choose a path toward productive and fulfilling lives. 


\section{Models for Educational Structures at the Mid-Level}

The middle school movement developed out of a desire to form developmentally sensitive, academically appropriate schools to handle the education of students during this middle level of education. Prior to this movement there was a tendency to either treat students at this level as elementary students or as miniature high school students. Much research has been done in the development of the elements that would make up an ideal middle school.

In 1992, a group of researchers for the National Middle School Association (NMSA) in a report titled This We Believe developed a list of what they believed should characterize developmentally responsive middle schools.

The National Middle School Association believes: Developmentally responsive middle level schools are characterized by:

- educators committed to young adolescents

- a shared vision

- high expectations for all

- an adult advocate for every student

- family and community partnerships

- a positive school climate

Therefore, developmentally responsive middle level schools provide:

- curriculum that is challenging, integrative, and exploratory

- varied teaching and learning approaches

- assessment and evaluation that promote learning

- flexible organizational structures

- programs and policies that foster health, wellness, and safety

- comprehensive guidance and support

(NMSA, p.11)

This list is similar to the list presented by the Carnegie Council in Turning Points in 1989. All of this is done in an attempt to override the developmental mismatch of dramatic school structural change at a time when so much other dramatic change and upset is occurring in the life of the early adolescent. 
The middle school movement has tried to structure middle schools in ways that would help make schools more developmentally appropriate. Exemplary middle schools seem to share various elements that are there in an attempt to meet the need for a more positive school environment. For example, typical middle schools are often structured in teams, have heterogeneous grouping, develop a curriculum that is student centered, have a curriculum that is integrative and exploratory, and have teachers that are specifically trained to work with this age group. The following section will examine the research on these elements of middle schools.

\section{Teaming}

Structuring schools in teams has been an attempt to solve the problems that students face once leaving the smaller elementary school setting. Often students leave small personal settings to face large impersonal settings at a time when they are already starting to feel lost. In order to have more flexible organizational structures and a positive school climate, middle schools have tried to structure small communities for learning inside the larger school structure. This has been accomplished by using teaming. According to Knowles and Brown (2000) teaming is the placing of students in heterogeneous groups that stay together and move through their classes together throughout the day. Each team usually has from 2-4 main teachers rather than the 6 or 7 that a student might have in a large junior high setting. The most common teaming structure has math, science, language arts, and social studies teachers handling 100 to 125 students. 
A variety of researchers have found that the purpose of teaming is to allow students and teachers to get to know each other better in smaller units. There is evidence in the research that teaming benefits both teachers and students. It reduces teacher isolation and can help them plan learning for their team that will appropriately meet the need for social, emotional, and academic growth (Berkowitz, J. \& Uline, C., 1999). The best use of teaming is suppose to be when teachers have common planning time so that they can structure the learning of their team together across each teacher's subject area to form interdisciplinary units. Teaming is supposed to allow them to use flexible time structures to provide a varied teaching and learning experience. However, in realistically looking at the research in this area, it appears that little interdisciplinary planning actually takes place (Walley \& Gerrick, 1999), (Weilbacher, 2000), (Elmore, 2000), (Storz, M. \& Nestor, K., 2003).

An advantage of teaming over departmentalization is the opportunity to plan for flexible scheduling. In self-contained elementary classrooms, teachers can set aside whole days or whole afternoons to work on interdisciplinary, hands on learning activities. It is much more difficult to pull off these kinds of activities if the school is tied to 40 minute class periods with no flexibility. Part of the idea of teaming is that the four teachers can work together and flex when they need more time to carry out creative, active learning scenarios.

\section{Heterogeneous Grouping}

Another part of the teaming principle is heterogeneous grouping. Students are put together with other students of varying ability. One of the criticisms of junior high was 
that most of them used tracking. According to the Third International Math and Science Study (TIMISS), Germany and the United States are the only developed countries in the world that practice tracking. Researchers have found that if students are not introduced to challenging math and sciences courses during middle school, it is found that they will not be likely to take these kinds of classes later in their education (Bandlow, 2001). What constitutes an excellent education for one student should be available to all students not just those students that do well on academic tests or go to wealthy district schools.

\section{Student Centered}

Another element of exemplary middle schools is student-centeredness. In this view of schooling, education centers on topics that are related to the world of students at this level. Much of this is supposed to be accomplished by involving students in the decision making process (Hargreaves \& Moore, 2000). Gehlbach and Roeser (2002) comment on the mismatch for adolescence when they enter larger schools after elementary and have no choice about anything in their environment. In order to help make learning more relevant and maintain a curriculum that is challenging and exploratory, teachers in middle school need to tap into student ideas and choices in planning. Students seem to become more motivated when given the opportunity to make some of the decisions about the goals for their learning. Professors Malloy and Rayle from the University of North Carolina looked closely at a middle school development program called the Comer Process. In this process of building a school, three principles guide it: consensus, collaboration, and no-fault. (2000, p.13). 
Along these same lines other schools have encouraged a democratic atmosphere in their schools by creating ways for students to participate in writing rules for the classroom. This seems to be a bit time consuming in the beginning of the year, but the benefits seem to make the effort worth it. In order to maintain a positive school environment, developmentally, students of this age need to understand the idea of community and the rule of law. When they have logically deduced the rules for their setting, there is evidence that they take more ownership in following them or accepting discipline when the do not follow them (Frost, R., Olson, E. \& Valiquette, L., 2000). In a classroom where the atmosphere is warm and comfortable and the children feel safe, learning is better facilitated. Involving students in decision making about rules helps them to learn about democracy and develop a moral sense for the purpose of rules and laws in society.

\section{Curriculum}

Finding the ideal curriculum and learning theory for middle school that is challenging, integrative, and exploratory is another hot point in the issue of structuring schools. Ideal middle schools, according to Anderman, Maehr, and Midgley (1999), in general try to develop a curriculum that is task focused rather than performance focused. The latter is more concerned with demonstrating ability or hiding the lack of ability. There is more of a focus on competition and there is more ability grouping in performance based learning. In task-focused learning, learning for the sake of learning is emphasized. There is a focus on mastering the task. Often problem solving and 
cooperative activities are employed in the learning. Grouping is based on need or interest rather than ability.

In dealing with educating students at the mid-level, teachers and educators have to align their focus. Traditional junior high settings were departmentalized by subject and focused on preparing students in subject areas for high school. Middle schools, in theory, are more concerned with educating students in a connected meaningful way than they are about subject matter in specific areas (Berkowitz, J. \& Uline, C., 1999). Educators also have to find developmentally appropriate ways to tap into the energy and enthusiasm of students at this level. Lancaster and Rikard (2002) report that recent brained-based research has found that classrooms need a variety of methods to reach every child. Using hands-on activities and cooperative learning activities in which the students teach other students can account for a $90 \%$ retention rate in students. Making learning activities as active as possible seems to be most appropriate for students at this level.

Finding ways to take the curriculum outside is another way to actively engage students of this level in learning. One of the findings in Lounsbury and Johnston's classic study Life in the Three $6^{\text {th }}$ Grades (1988) was the amount of time students spend indoors often without even the benefit of a window. Many of the shadow researchers commented on how good it felt to be outside when the student they were shadowing was allowed out for recess or lunch. Broda of Ashland University in Ohio advocates the use of the outdoors in education to fit with the type of intellectual development that is occurring in the middle grades. He found that it fits well with many of the "best practices” for this level. The learning situation can add relevance to what is being learned. In order to use the outdoors in education there needs to be flexible scheduling 
where longer blocks of time are available. The outdoors provides an excellent setting for hands-on activities. It appeals to the idea of multiple intelligences. Some students are fascinated by nature and will learn more efficiently when things are tied to it. Outdoors there is plenty of room to spread out for cooperative learning activities. Finally, nature can be used as the tie between interrelated subjects to create connectedness across subject areas (Broda, H., 2002).

\section{Motivational Drop}

Research has documented the drop in motivation that comes with the transition to middle school or junior high. Researchers Anderman, Maehr, and Midgley of the University of Michigan (1999) found in a quantitative study of two middle schools that had qualitative differences in their structure of learning that the type of school attended can affect that motivation drop. In their study, they looked at two middle schools; one had a more performance orientation more along the lines of a traditional junior high while the other had a more task oriented focus more along the line of middle school reform. They found that the students in the more task oriented school had less of an achievement drop than did the students in the more traditional school. This study seems to indicate that the achievement drop at this level is not just caused by the nature of early adolescence or by the society, but that how schools are structured can be a factor in the drop (Anderman, E., Maher, M., \& Midgley, C., 1999). Providing a curriculum that is challenging, relevant, and interconnected using a variety of methods that make learning active rather than passive is what the middle school reform is all about. 


\section{Teachers}

In looking at all of the research on building effective middle schools, there is no aspect that is more important than the teacher. Lounsbury and Johnston in Life in Three $6^{\text {th }}$ Grades studied three $6^{\text {th }}$ grades using three different structures. They looked at $6^{\text {th }}$ grade in self-contained classrooms, in departmentalized organizations, and in teamed settings. They found that overall it was “...not the school setting or organization, interdisciplinary units, relevant curriculum content, or anything else, that is the essential factor in the improvement of middle level education. It is the quality of the classroom teacher. Teachers make the difference.” (1988, p.112). In light of this, change in teacher certification in many states is an exciting development for mid-level reformers.

Over the years of the middle school reform movement, there has been a need for teachers that have been specifically prepared to deal with middle childhood students. These new teachers are committed to students at the middle school level. They are more rigorously trained in two areas providing a stronger background and more expertise in the areas that they become certified to teach. In the late sixty's to early seventy's only a handful of states had any special credentials for teaching at this level. In 2000, Peggy Gaskill, the director of Middle School in Education Program at Walden University in Minnesota, conducted research on the current status of licensure and credentialing for mid-level teaching in the various states in the U.S.A. She found that there has been a $75 \%$ rise in the number of states requiring a mid-level credential (2002, p. 38). The only states currently not requiring mid-level certification are California, Idaho, Louisiana, Maryland, Mississippi, Montana, and New Jersey (p.35). The major impact of this requirement is on teacher education institutions. Few colleges or universities offer 
specific mid-level preparation courses unless it is required by their state offices of teacher preparation and certification (p. 38).

Presently only $50 \%$ of the states requiring certification for mid-level are using it as a determining factor in hiring practices. Only $41 \%$ of the states require it for teaching at this level. Many worry that it is going to become difficult to require it for teaching at this level because of impending teacher shortages. "Demographics predict that the administrative and teaching force in the United States will turn over by up to $75 \%$ within less than ten years.” (p.39) Much depends on teacher training institutions continuing to prepare graduates to teach at this level. In many ways the continued survival of the middle school movement reform will depend on young teachers being prepared to carry it on (George, 1999).

\section{Criticism of the Middle School Movement}

While much progress in the education of early adolescents has been made in the last twenty years, it has not been without it critics. Falling test scores in comparison to other developed nations have caused many politicians and parents to begin pointing fingers. Critics claim that the middle school reform has placed too much emphasis on the emotional/social well-being of the child at the expense of providing academic rigor. Others claim that the understanding of early adolescence which was the foundation of the movement was based on an understanding of white, middle class adolescence which is not necessarily the same understanding across cultures. All adolescents face similar struggles, but the context for those struggles can differ greatly from community to community (Williamson, R. \& Johnston, J.H., 1999). 
Beane found that there are many difficult factors in evaluating the effectiveness of middle school structures and methods. First of all, many who criticize the reform, base their criticism on achievement test scores. The problem with this is that all schools with the name middle school are lumped together in one group. When this is done, achievement scores generally do not show improvement. However, there is a great disparity in the actual practices of middle schools. Some are middle schools in name only. Others have worked for a long time to really try to implement and practice exemplary model middle school elements. Most other middle schools are somewhere in between those two extremes because they are just on the edge of trying to implement and practice ideal elements of middle schools. Several large scale studies have indicated that the kind of middle school attended can greatly affect achievement scores. "Schools that seriously pursued the middle school concept with high fidelity over a number of years fared better on measures of both academic achievement and social behavior than their counterparts in schools that were in early stages of reform or had pursued change only half-heartedly.” (Beane, 1999).

It becomes clear that while many educators agree about the needed components for effective middle schools, the actual implementation and practices have been slow in coming. A recent study by Anfara and Waks (2000) found the following statistics about the actual practices in schools. Of 73 schools studied only 14 had advisories, only 6 had interdisciplinary teams, only 5 utilized flexible scheduling, and 0 had an exploratory curriculum. Middle school seems to be more of an ideal than a reality. The irony of it all is that low achievement at the mid-level is being blamed on developmental features of schools that in most case do not actually exist (Beane, 1999). 
Many of the reformers in the middle school movement do not feel that achievement test scores really reflect the types of curriculum and instructional changes taking place. However, there is a lack of stability in the area of coming up with a kind of assessment that would reflect whether positive change is taking place. Even when funded by massive amounts of money from places like the Clark foundation, many urban middle schools are not able to demonstrate improvement (Lewis, 1996).

A key element in the criticism of middle schools has been their lack of academic rigor. To many people, it seems as if a student-centered curriculum where students are allowed to grow and discover their own interests will leave them unprepared for high school and college (Bandlow, 2001). The lack of rigor at this level is usually blamed on two things. One is the belief that because of raging hormones early adolescents are incapable of intellectual growth. The other is the number of teachers at the mid-level that teach with elementary licenses and lack knowledge levels needed to teach subject matter in a rigorous manner to students at this level (Norton, 2000). Even though recent studies have found that early adolescents are at a time where they grow intellectually, many educators still hold a false understanding of this. In a national survey, nearly half of all administrators and teachers still believed that students at this level were at a learning plateau (Callahan, Tomilinson, Reis, \& Kaplan, 2000). Cognitive psychologist have noted that contrary to previous belief that brain growth leveled off in early adolescence, it has now been found that mid-level students are able to develop higher levels of logic and reasoning when they are given access to content knowledge. The standards signal that it's time to replace the picture of middle-grades students as captives of 'raging hormones' 
with one of young people fully capable of developing "raging intellects.' (Wheelock, 1996).

Linda Perlstein (2003)in her book not much just chillin' notes that Middle school students are not just satisfied with being given content. They want to know the why of things (p. 115). However, along this line has also been the push for a standardized curriculum that comes with state and national testing. The time needed to prepare for these tests often leaves teachers little time to deal with the why of things. Beane reports that most of these tests and curriculums follow the traditional subject area lines such as English, history, geography, mathematics, and science. He believes that this is causing many middle schools to fall back to a junior high subject-centered approach in order to prepare for test performance (Beane, 1999).

With the emphasis on test scores and achievement, many parents are attacking the basic structures of middle school reform. Williamson and Johnson (1999) report that many parents, especially middle class ones, are demanding a return to ability grouping and competitiveness in the school structure. Many middle schools have found that exploratory classes and interdisciplinary units are not taken seriously by parents or students. Parents fail to see how they impact what the student need to know, and students see them as a break from the "real” learning (Williamson, \& Johnston, 1999).

Despite the fact that one of the tenets of the middle school movement was parental involvement, Williamson and Johnson (1999) say that many parents find the schools unresponsive to their inquiries. Assuring parents that schools know best is not working with most parents anymore. They believe that middle schools need to welcome parent questions and set up advisory councils to deal with them. 
Parents also see the behavior in middle schools as chaotic. Students have even commented in surveys that students swear and teachers ignore it. They look for teachers to intervene and provide a safe environment for them to learn in and they do not always find it in large middle schools (Williamson, \& Johnston, 1999). Parents are also confused by the interdisciplinary units. Students enjoy them, but parents cannot always see where they fit into the overall scheme of what their children should be learning.

Middle schools often are seen as just trying to reform according to some checklist of ideals for education at this level. In order for this movement to continue, it is going to have to adjust and become willing to develop along the lines that are needed by individual communities. Learning is going to need to be driven by standards and the issue of achievement is going to need to be addressed and not avoided. All students need to be given access to the kind of learning that is going to enable them to continue to succeed as they move on through the system.

\section{The Development of the Christian Day School}

The development of the middle school as a structure for educating students at the mid-level occurred at about the same time as another movement in this country -- that is the development of private Christian day schools. Having Protestant Christian parents involved in the control of the education of their children is no new thing. Before the development of the public school movement, Protestant parents were often actively involved in the formation of schools for their children and in the formation of charity schools for the children of poor people (Kienel, 1998). However, as the common school movement developed and evolved into public education, most Protestant parents 
supported it because many protestant Christians were at the forefront of the development of these Common schools. The goal of early public schools was to make available education for all children in a way that would develop a civilized society of Christians (Carper \& Layman, 1995).

Without dwelling on the differences between various denominations of Protestant churches, traditional public schools reinforced a basic Judeo-Christian view of the world. These schools had Bible readings without comments, prayer, "moral" teachers, and strongly Christian textbooks like the McGuffey readers. Unsurprisingly, by the late 1890 's $86 \%$ of children from ages 5 to 14 were enrolled in public schools. The majority of private schools at that time were Roman Catholic schools which enrolled about $11 \%$ of the school age population (Carper \& Layman, 1995).

Predominant views in American society began to change in the 1900's and by the time of the 1960's public school reform was changing education. Many factors led up to these changes. A. James Reichly (1985) in Religion in American Public Life says that since the 1950's the value-belief system of the United States had changed. Science and reason were believed to hold the keys to progress and knowledge. There was no room for a deity in the affairs of men. This evolutionary view of the cosmos became the dominant view in the intellectual community. It also began to hold much sway over the entertainment industry, the media, and parts of the educational enterprise.

A significant minority of unhappy parents began to form. Carper and Layman report that groups of Protestant began to become alarmed at the changes that were beginning to occur in public education. The teaching of evolution as the only explanation for the beginning of our world coupled with prayer and Bible reading being expelled 
from the classroom caused much dismay to many conservative Christians. At the same time the middle school movement was proclaiming the importance of age-appropriate education and the need for sex education in public schools. This caused many of these parents to become fearful that the education provided by the public school system would run counter to the education of the home and church (Carper \& Layman, 1995), (Beane,1999).

By the mid-1960's many parents belonging to evangelical and fundamentalist Protestant churches started forming Christian day schools or academies. According to Edmund (1999) and Carper and Layman (1995), very few of these churches were part of any mainline Protestant denomination. Most of the schools formed in this movement have been independent schools that were formed by individual independent churches. As the movement has grown some board run schools that are independent of one direct church association have also been founded. Carper and Layman found that it is hard to know how many Christian day schools exist because many of them refuse to join a larger association of schools and do not report details about their enrollment to state or federal agencies. However, the best estimate is that from 8,000 to 12,000 have been started since the late 1960's. As of the early 1990's, it has been estimated that $20 \%$ of all privateschool students are in these types of school. That means that private Christian day schools are educating around a million students in grades K-12.

These schools reflect the values and ideas of the parents and churches that support them. Much of the movement has been characterized by a desire to return to the good old days when public schools were influenced by an emphasis on good morals and basic knowledge in reading, writing, and arithmetic. Consequently, at least, in the early school 
development, they tended to be structured very traditionally. Many use a very traditional Christian curriculum published by Pensacola Bible College called Abeka. A curriculum published by Bob Jones University is also popular in many Christian day schools. The teaching of evolution in public schools is still a hot spot for most of the parents of Christian school students (Stover, 1999). Stover reports that the 1987 Supreme Court decision banning the teaching of creation in public schools has been a factor in causing parents to withdraw their students from public education. Therefore, any textbook that has even a passing reference to evolution is often not used in most Christian day schools. Many parents chose private Christian day schools because they realize the effect of peer pressure on school age students (Walley, \& Gerrick, 1999). They also desire to have teachers that are of like-faith as role models for their children. Much research has been done to validate the importance of positive role models for adolescents. Research also demonstrates the importance of friends during this time period. Parents feel that by placing their son or daughter in a Christian school they will find it easier to develop strong friendships with other students that are of like faith. Researchers Roeser, Eccles, and Sameroff (2000) found that students were more likely to be academically motivated when they were in environments where they felt respected and cared for by both classmates and teachers. Researchers Issler and Habermas (2002) found that one strength of the mid-level education in Christian day schools is the idea of spontaneous modeling. Students spend their days with teachers and hopefully other students in which they see a model for living by how they live their lives. Spontaneous modeling is not planned, but it is how teachers and students reveal their true character in every day events and 
conversations. Researchers on middle schools acknowledge the powerfulness of having teachers, students, and curriculum share common cultural beliefs.

The spontaneous modeling that is a strong selling point for Christian schools is also believed to be important in moral development. Because early adolescence is such a key time in moral development, many parents sense the importance of having their children in a school that will complement the moral message that students are receiving at home. Many parents feel that Christian day schools are the best setting for a moral climate that is appropriate. In a survey by Walley and Gerrick (1999) of over 2000 adolescents, it was found that adolescents do see a need for guidance in understanding the moral perspective on issues. They do not see a conflict when considering the influence of authority figures as wells as peers and their personal beliefs.

The school reform movements from the 1960's until the late 1980's have tried to have moral training in public schools. It, however, has mostly been an attempt to make students aware of their moral reasoning. It also strived to improve the quality of students' moral reasoning, but care was given not to pass judgment on anyone’s moral decisions. This led many Christians to accuse the schools of teaching students embrace moral relativism. Many parents felt that it was against their beliefs in the moral absolutes stressed in the Bible to have their children schooled in a setting in which relativism was stressed (Alegra, \& Sink, 2002).

Private Christian day schools have traditionally been schools that have focused on being college preparatory schools. The small size and the lack of funding for developing classes in other career pathways has caused most of these schools to provide mainly a classic college bound program. This has not caused much problem to parents because 
they are of a socio-economic level if they can afford tuition that would cause them to expect a college preparatory education for their children.

Parental involvement is also an advantage of many Christian schools. Oosterhuis (2002) found that because Christian schooling is paid for by tuition dollars, parents are often more willing to invest their time and energy in volunteering and developing the sense of community in the school. Christian day schools are often smaller than their public counterparts. He also found that the circle of relationships between school families is often strengthened by attending common churches. Parents are often board members of these private schools. Parents tend to take more pride and ownership of the school and its success because they have helped start the school and they feel they have a voice in how it continues to operate. Many times parents feel free to approach teachers, administrators, and board members with problems and questions. If nothing else, the parents know that if they are unhappy about the direction a particular school is going, they can always pull out and go somewhere else. The administration of these schools has found that to stay competitive they must stay open to parent's opinions about how the school should be run (Oosterhuis, 2002).

Teachers in Christian day schools tend to be professionals that feel called to work in Christian education. They are often paid a significantly lower salary than their public school counterparts. Researchers, Joe P. Sutton and Timothy G. Watson (1995), education professors from Bob Jones University, surveyed Christian day school teachers about the biggest problems in Christian schools today and found that top-ranked problem was low teacher salaries. Yet despite these lower salaries many dedicated professionals continue to teach in these schools because of their desire to help prepare students 
mentally, emotionally, and morally to function in this world. Many teachers in these schools find the quality of students and support that they receive from the family makes their job of teaching in Christian schools a little easier than their public school counterparts. Perlstein (2002) found that teachers will sacrifice receiving a higher salary to work with students that are from families that support high academic standards.

\section{Christian School Structures}

Very little research exists about the educational structures found in most of these private Christian day schools. Many schools have been reluctant to allow outside researchers to come in for the fear of government interference. Most of these schools refuse government funding and are supported in a large part by tuition paid by parents. The goal of this researcher is to make a cross-sectional examination of current practices at the mid-level in Christian day schools. By nature of being smaller institutions with strong parental support, the researcher expects to find that many of the qualities called for by middle school reformers already in existence in many of these schools.

For example, teachers that are committed to adolescence would be expected in these schools because teaching in these schools is usually a sacrificial choice made by those educators. However, it will be interesting to find out how many of the teachers have had specific preparation for educating students at the mid- level. Another area that should be strong is parental involvement and the sense of community as a result of the common faith bond shared by the school and its constituents. One would also expect a positive school environment with a shared vision for the school. 
The researcher will examine the perceived presence of these factors as well as examining the school structures and curricular provisions of these schools. Examination of the type of curriculum will include seeing if it is challenging, integrative, and exploratory. Observation of the teaching and learning approaches will also be made. The types of organizational structures will be surveyed. The presence of programs that focus on health and safety will be looked for in these schools. Finally, the support systems for each individual student will be examined (NMSA, 1992).

As Christians many of the goals of the middle school program should be attractive. Biblically, the development of community and the morality of the children is continually stressed. Researchers have tried to determine the best ways to educate the unique time period of adolescence. It will be interesting to learn if Christian schools include any of these best ways, and if they do not, is there a willingness to develop in areas where they are weakest. 


\section{CHAPTER III.: PROCEDURES AND RESULTS}

\section{Research Procedures}

After a thorough review of the literature on the best practices for middle school education, the researcher designed a checklist of the key areas that would demonstrate the type of model for grades 5-8 being used at each school (see Appendix A). With this checklist in mind the researcher developed the plan for gathering data from a cross section of Christian schools.

The data was gathered by Cedarville University students who were doing a required observation week in a Christian school of their choosing. Most of the students chose to do this observation in their home town which provided the researcher with eighteen sets of data from a variety of schools in various locations. Using this process the researcher gathered nine sets of data from Ohio schools, three from New York schools, and one from Virginia, Florida, Colorado, Pennsylvania, Michigan, and even one set from Bermuda.

Before the students gathered this data, the researcher met with them and talked to them about the project and the procedures for collecting data. At these meetings the students were given packets containing the directions, forms, and interview questions that they would need for the data collection.

The first page of the packet had the basic instructions for the project (Appendix B). Students were instructed to give a letter and a survey to the administrator the first day of their observation (Appendix C and D). Each student researcher was allowed to choose to shadow either a teacher or a student. The procedures to shadow either a student or a teacher varied slightly. Because of this there was included in the packet, directions for 
shadowing a teacher and for shadowing a student (Appendix E). Whether the researcher was shadowing a teacher or a student, the plan was to write down observations about what was happening in the classroom every five to seven minutes. In order to do this, several blank observation forms were included in the packet (Appendix F). On the observation form, the researcher was to record the time, the specific behavior, the environment, and an impression/comment. If the university student was shadowing a student, a permission slip (Appendix G) was sent home and approval was gotten for the researcher to interview the shadowed student. At the end of the day or the next day whether a student or teacher was shadowed, the university student was to interview the person that he or she shadowed that day (Appendix H and I). Finally, the Cedarville student was asked to fill out an end of the day reflections of the researcher for their impressions about the day (Appendix J).

\section{Analysis of the Observations}

After all of the data sets were turned in, the researcher began to go over the data using the checklist from Appendix A to begin to gather a picture of a day in the life of a student or teacher in a Christian school. One thing began to emerge as the researcher examined the data, despite the fact that these schools were in a variety of locations, they were all very similar to each other. The size, the structure, the flow of the day was somewhat similar in all of the schools.

In order to analyze the data gathered by the student observers taking observations every five to seven minutes, another chart was designed that would provide a picture of what was happening in the class rooms observed. After reading through the collected 
data several times, the researcher designed a list of the typical activities that were reported on the observation forms. Some of the student observers were more vigilant about taking an observation every five to seven minutes. Therefore, the number of observations for each school varied from as low as thirty observations recorded to as high as sixty-six observations. For comparison sake, the researcher tallied the observations in each area and then turned them into a percentage based on the total number of observations taken for that school.

To begin analyzing the data, a random number was assigned to each school. Then each observation was tallied on the Chart of Activities (Appendix K). The Chart of Activities on the following two pages gives a quick view of the types of things that were happening in these classrooms. The great variety of activities in each classroom throughout the course of a day was very interesting. Many of the schools had working on an independent assignment as one of their highest percentages. When one considers the teacher led activities such as lecture, discussion, review, class games, and class grading papers together, they were the highest percentage of the day for most of the classrooms. The uniqueness of this type of study is in the fact that it is just a quick snapshot of a typical day in this type of school. On the following page is the chart showing the results of tallying the observations and turning them into a percent based on the total number of observations taken. 


\section{Chart of Activities Observed}

\begin{tabular}{|c|c|c|c|c|c|c|c|c|c|}
\hline & 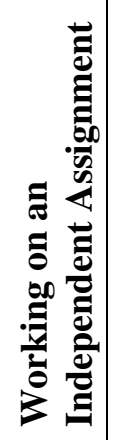 & 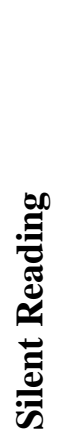 & 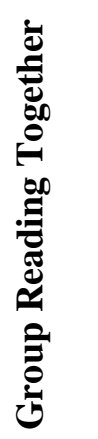 & 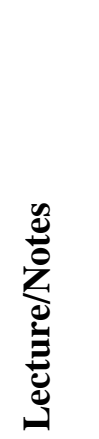 & 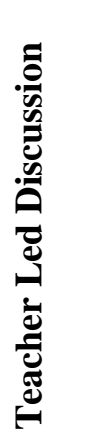 & & 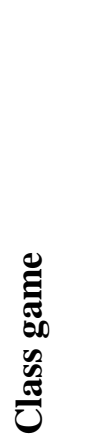 & لَّ & 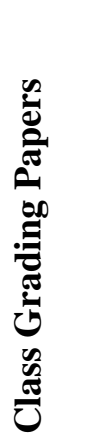 \\
\hline 1 & $19 \%$ & $2 \%$ & $7 \%$ & $2 \%$ & $7 \%$ & $7 \%$ & $2 \%$ & $4 \%$ & - \\
\hline 2 & $17 \%$ & - & - & $20 \%$ & $10 \%$ & $27 \%$ & - & $13 \%$ & - \\
\hline 3 & $3 \%$ & $3 \%$ & $10 \%$ & $7 \%$ & $10 \%$ & $7 \%$ & - & $3 \%$ & $13 \%$ \\
\hline 4 & $22 \%$ & - & - & $6 \%$ & $13 \%$ & - & - & $26 \%$ & - \\
\hline 5 & $19 \%$ & - & $12 \%$ & $6 \%$ & $14 \%$ & $1 \%$ & - & - & $1 \%$ \\
\hline 6 & $30 \%$ & - & $7 \%$ & $4 \%$ & $6 \%$ & - & - & - & - \\
\hline 7 & $5 \%$ & - & $12 \%$ & $10 \%$ & $17 \%$ & $5 \%$ & - & - & - \\
\hline 8 & $2 \%$ & - & $6 \%$ & $18 \%$ & $6 \%$ & $3 \%$ & - & $2 \%$ & $8 \%$ \\
\hline 9 & $3 \%$ & - & $6 \%$ & $11 \%$ & $21 \%$ & $8 \%$ & - & - & $5 \%$ \\
\hline 10 & $30 \%$ & - & $4 \%$ & $15 \%$ & $5 \%$ & - & $9 \%$ & - & - \\
\hline 11 & $22 \%$ & - & - & $15 \%$ & $3 \%$ & $2 \%$ & - & $7 \%$ & $10 \%$ \\
\hline 12 & $28 \%$ & - & $6 \%$ & $11 \%$ & $9 \%$ & - & - & - & $3 \%$ \\
\hline 13 & $19 \%$ & - & $3 \%$ & $10 \%$ & $10 \%$ & - & - & - & $6 \%$ \\
\hline 14 & $7 \%$ & - & $2 \%$ & - & $5 \%$ & $5 \%$ & - & $7 \%$ & $2 \%$ \\
\hline 15 & $10 \%$ & - & - & $8 \%$ & $2 \%$ & - & $5 \%$ & $10 \%$ & - \\
\hline 16 & $48 \%$ & $4 \%$ & $7 \%$ & $7 \%$ & - & - & - & $17 \%$ & - \\
\hline 17 & $38 \%$ & - & $4 \%$ & $6 \%$ & $11 \%$ & $2 \%$ & - & $9 \%$ & $4 \%$ \\
\hline 18 & $26 \%$ & $3 \%$ & $5 \%$ & $19 \%$ & $7 \%$ & - & $5 \%$ & $7 \%$ & - \\
\hline
\end{tabular}




\section{Chart of Activities Continued}

\begin{tabular}{|c|c|c|c|c|c|c|c|c|c|c|}
\hline & 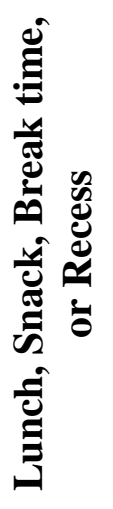 & 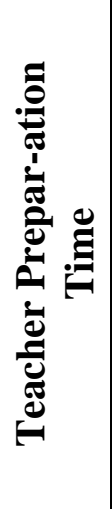 & 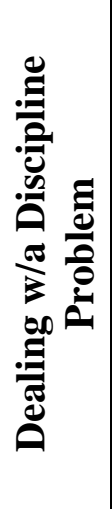 & 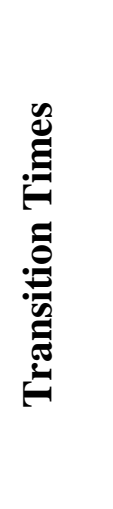 & 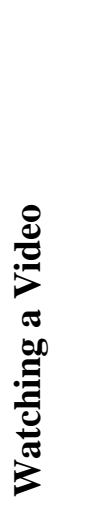 & D & 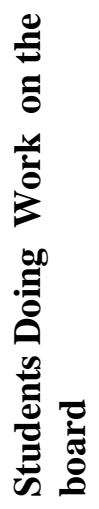 & 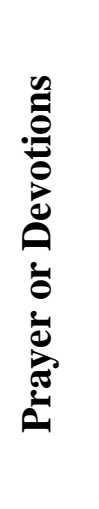 & 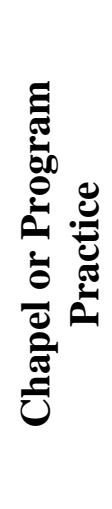 & 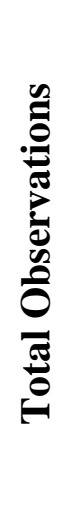 \\
\hline 1 & $23 \%$ & $7 \%$ & - & $9 \%$ & - & - & - & - & $9 \%$ & 53 \\
\hline 2 & $3 \%$ & - & - & $7 \%$ & - & - & - & $3 \%$ & - & 30 \\
\hline 3 & $10 \%$ & $10 \%$ & $3 \%$ & $20 \%$ & - & - & - & - & - & 30 \\
\hline 4 & $10 \%$ & $10 \%$ & - & $13 \%$ & - & - & - & - & - & 31 \\
\hline 5 & $3 \%$ & $5 \%$ & $3 \%$ & $15 \%$ & $5 \%$ & - & $3 \%$ & $3 \%$ & - & 64 \\
\hline 6 & $19 \%$ & $9 \%$ & - & $2 \%$ & - & $19 \%$ & - & $2 \%$ & - & 46 \\
\hline 7 & $12 \%$ & $15 \%$ & $2 \%$ & $20 \%$ & - & - & - & $2 \%$ & - & 41 \\
\hline 8 & $6 \%$ & $16 \%$ & $3 \%$ & $19 \%$ & - & - & - & $15 \%$ & - & 62 \\
\hline 9 & $14 \%$ & $8 \%$ & $3 \%$ & $11 \%$ & $5 \%$ & - & - & $14 \%$ & - & 63 \\
\hline 10 & $6 \%$ & $11 \%$ & $1 \%$ & $17 \%$ & - & - & - & $1 \%$ & - & 66 \\
\hline 11 & $10 \%$ & $8 \%$ & $8 \%$ & $12 \%$ & - & - & - & $2 \%$ & - & 59 \\
\hline 12 & $14 \%$ & $11 \%$ & $3 \%$ & $6 \%$ & - & $6 \%$ & - & - & $3 \%$ & 35 \\
\hline 13 & $13 \%$ & $13 \%$ & - & $13 \%$ & $10 \%$ & - & - & $3 \%$ & - & 31 \\
\hline 14 & $9 \%$ & $9 \%$ & $2 \%$ & $16 \%$ & $14 \%$ & $7 \%$ & - & - & $14 \%$ & 43 \\
\hline 15 & $12 \%$ & - & - & $15 \%$ & $8 \%$ & - & - & - & $30 \%$ & 40 \\
\hline 16 & $9 \%$ & - & - & $9 \%$ & - & - & - & - & - & 46 \\
\hline 17 & - & - & $4 \%$ & $15 \%$ & - & - & - & - & $6 \%$ & 47 \\
\hline 18 & $15 \%$ & - & - & $9 \%$ & - & - & - & $3 \%$ & - & 58 \\
\hline
\end{tabular}


The timing of when these observations were taken does have some impact on the results. The first third of my student observers made their observations in the week before Christmas vacation. Several of the schools had unusual schedules because they were preparing for a Christmas program or because they had special chapel services. Despite this timing of the observations, some patterns appear in the data. All of the teacher led activities were combined into one percentage in the following chart so that a comparison of typical classroom activities could be made.

\section{Activity Comparison}

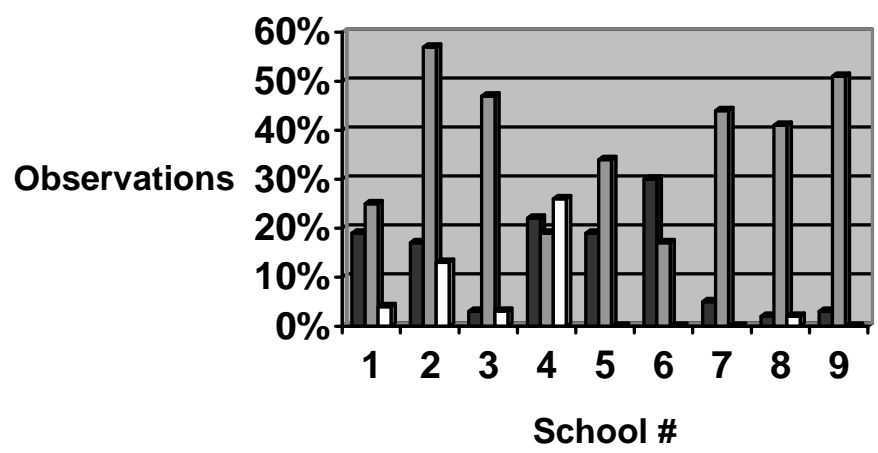

\begin{tabular}{|l|}
\hline Independent \\
Activity \\
$\square$ Teacher Directed \\
Activity \\
$\square$ Cooperative \\
Learning Activity \\
\hline
\end{tabular}

\section{Activity Comparison Continued}

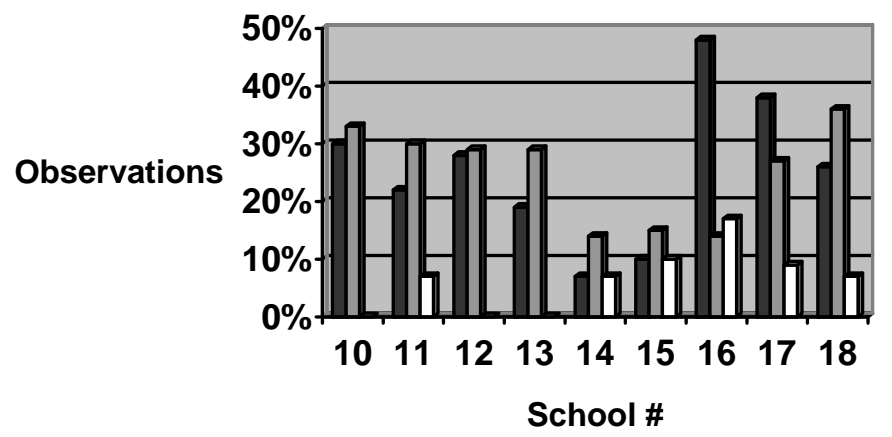

\begin{tabular}{|l}
\hline Independent \\
Activity \\
$\square$ Teacher Directed \\
Activity \\
$\square$ Cooperative \\
Learning Activity
\end{tabular}

School \# 
The graphs demonstrate the amount of time spent in teacher directed activity and independent activity to be quite high in most of the schools observed. Cooperative learning was used in a limited way in eleven of the eighteen schools studied. One school had $19 \%$ of its observations be of student presentations. The observer did not mention whether these were group presentations or individual presentations. The results in these graphs seem to indicate that most of the schools observed were performance oriented and teacher-centered.

In terms of moral development the following graphs will look at the time spent in chapel, devotions, or dealing with a discipline issue. Although the percentages of time spent are low, almost every school spent some time in one of these three areas.

\section{Moral Development Activities}

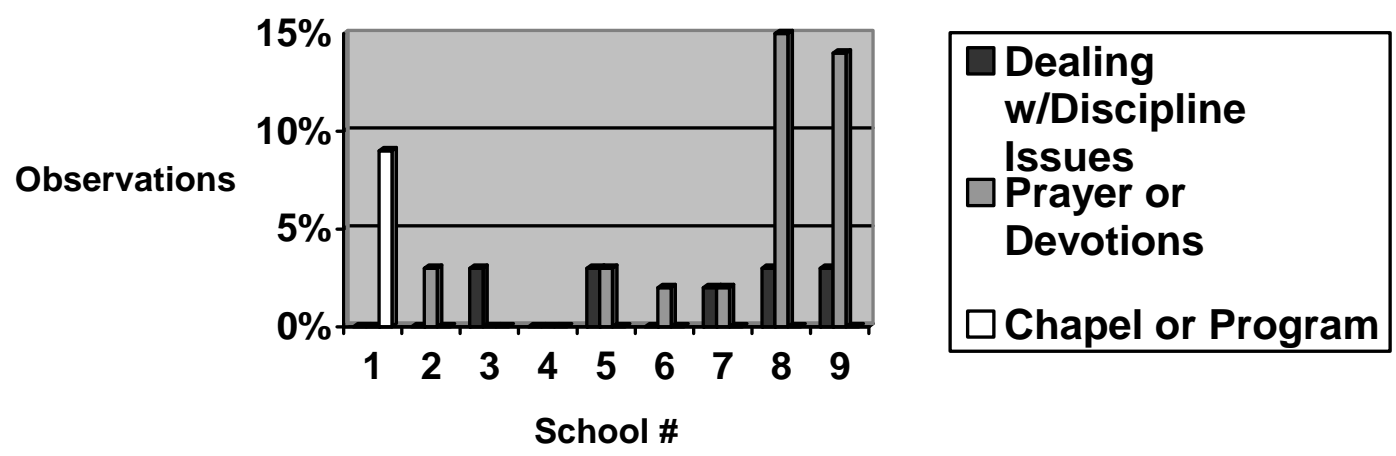

\section{Moral Development Activities Continued}

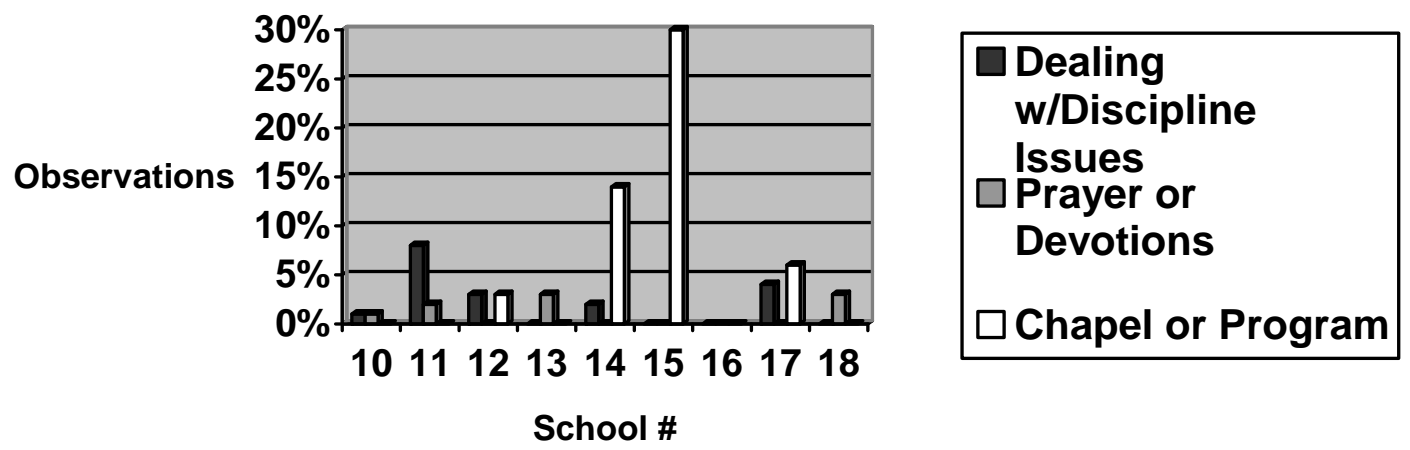




\section{Administrative Survey Data}

The administrative survey gave information about the size and structures of the various schools. Unfortunately, one set of data did not have a completed administrative survey. However, all of the other sets did have the survey giving the researcher basic information about 17 of the 18 schools in the study.

The size and structures of the schools were very similar. The survey showed that eleven of the schools ranged in size from 100 to 400 students. Six of the schools had more than 400 students. Three of the schools served grades Kindergarten through eighth grade while the other thirteen served Kindergarten through twelfth grade.

Most of the schools had a traditional structure for the middle grades. Eleven

schools were divided between sixth and seventh grade. Kindergarten through $6^{\text {th }}$ grade in these schools was considered elementary and seventh grade through twelfth grade was considered secondary. The other five schools reported structuring grades kindergarten through fifth grade as elementary, grades sixth through eighth as middle school, and grades nine through twelve as high school.

All of the schools seemed well established because all of them have been in existence for more than twenty years. Six schools were twenty plus years old, eight schools were more than thirty years old, and three schools were more than forty years old. The combination of size and years of existence demonstrates that these are all established schools.

\section{Teacher Certification}

One of the perceived weaknesses in Christian schools is that there are often teachers teaching that are not certified. However, according to the administrative survey 
nine of the schools reported that almost all of their teachers have specific training for the level that they teach. Six of the schools reported that some have specific training, and one school reported that none of the teachers had specific training. The wording on the survey did not clearly ask if teachers of the middle grades had middle grade only certification. It can probably be safely assumed that most of the reported specific training would be through a basic grades 1-8 elementary certification or a secondary 7-12 certification.

\section{Plan for the Transition to the Middle Grades}

The administrative survey results showed that the majority of schools had at least a limited plan to ease the transition from the elementary grades to the middle grades. Three schools reported that students go from having one primary teacher to having several teachers without much specific preparation for that change. Two schools reported that students are gradually introduced to more than one teacher, but that nothing specific is done to ease that transition. Finally, twelve schools reported that they have specific plans in place to ease the transition of students from the elementary grades to the middle grades. All twelve schools mentioned that they gradually shift students from one teacher to many teachers. Most of them reported going from one teacher in elementary to two or three teachers in sixth grade, and then to four or five teachers in seventh and eighth grade. Six of the schools reported having parent meetings in fifth or sixth grade to help ease the transition. Six schools also reported that they had the transitioning students visit the middle grades for a day or part of a day some time in the spring prior to the year that they would make the transition. 


\section{Teacher Interview Data}

The strongest point of these schools seems to be their committed teachers. Fourteen of the eighteen sets of data collected were where the Cedarville student shadowed a teacher. Eleven of these teachers were female and three were males. The majority of the teachers had their own children in the schools. In the end of the day interviews, several of the female teachers mentioned that they felt that teaching blended well with being a mother. Many of the teachers mentioned feeling called to teach in a Christian school. Several commented that lower salary and fewer benefits for teaching in a Christian school was frustrating. However, despite that frustration, all of the teachers seemed committed and seemed to enjoy teaching at their school.

The circle of the community of home, school, and church seems very strong in these schools. Many of the teachers spoke of how much they enjoyed the freedom to speak about God and their relationship with him freely in their schools. Family partnership with these schools seems quite strong. Sixteen of the eighteen schools reported having strong parental involvement. Several teachers voiced the idea that often parents are more involved because they are paying tuition and feel more ownership for the school and what is going on in it.

\section{School Climate}

Most of these schools have a positive school climate. The school, the students, and the families usually have the best interest of the students at heart. Although most teachers indicated that students could talk to an adult if they had a problem, most of the schools did not seem to have a person that was specifically in the position of advocate for the students. The typical response on the majority of the interviews was that the students 
could always come and talk to a teacher or to the principal if they needed an adult to talk to about a problem. However, the interviews of several teachers indicated that students could come for help but that very few ever took advantage of being able to do that.

Several teachers mentioned the high expectations of the school; however this was usually mentioned in reference to high achievement test scores. The teachers and the students in the end of the day interviews indicated that they felt students were getting a good education at their school. Despite the perception of receiving a good education, there were very few instances of teachers using challenging, exploratory, or task oriented activities. Even integration of subjects including Bible did not come across in the data collection of observations.

In fifteen of the eighteen sets of observation, a Bible class, a chapel, or at least a gathering of prayer requests for a prayer time was observed. Several teachers commented that discipline was better at their school because they could deal with the misbehavior on a spiritual level. There were not extremely specific instances of moral development going on in every class. However, it does seem that the pervasiveness of prayer and the Bible points the students to the importance of their spiritual walk in every day aspects of life.

\section{Styles of Classrooms}

In order to have this harmony of spiritual beliefs in the everyday aspects of the classroom, something seems to be given up. All of the data sets indicated that the classrooms in these Christian schools were very teacher centered. One Cedarville student even commented on how much the teacher he was observing seemed to like his stool at the front of the class. In the end of the day interviews, most of the teachers honestly 
admitted that their curriculum did not allow for much in the way of students being allowed to make decisions. A typical day in these class rooms consisted of lots of teacher/student discussion or teacher lecturing. All of the schools seemed very performance oriented. Fifteen of the eighteen sets of data had significant amounts of time in which students worked independently on assignments, tests, or quizzes. Ten of the sets of data showed at least a limited use of cooperative learning such as working with partners at some point during the day. Only two of the classrooms observed had any kind of hands on or interactive type of learning activity on the day of the observation.

\section{Discipline Styles}

The various styles and levels of discipline was the area in which the most diversity from one school to the next was observed. In one classroom, the students were earning dollars to pay for a party. In four of the class rooms teachers used a lot of verbal reprimands and refocusing of attention without much action taken to back it up. In seven of the classrooms the teachers seem to use a balanced authoritative style of discipline in which they dealt quickly and consistently with misbehavior. In four of the observations, the teachers seemed very permissive in what they allowed to go on in their class rooms. In one of the student shadowing observations, it was difficult to settle on one style because the student moved from class to class.

The most obvious conclusion from observations of Christian schools is that middle school age students struggle with the same behavior issues that they struggle with in other settings. Middle school students love to make noise. In one observation a boy was continually making noise with his mouth. Another observer noticed excessive pencil tapping and stated that it was nearly driving her crazy. In almost all of the observations, 
the students loved to chatter any time that they could whether they were suppose to or not. Finally, it was clear from these observations, that if a teacher does not take charge of the students at this age, chaos will reign.

\section{School Structures}

In terms of school structures, very little evidence of teaming was observed. Most of the teachers stated that they did not work with other teachers in their daily planning of activities. Some referred to teaming because they worked with another teacher so that they could teach a subject more than once. Other than that the teachers all seemed somewhat independent of each other. In almost half of the schools, grades five and six were in self-contained or nearly self-contained class rooms. In eleven of the schools grades seven and eight were departmentalized and had a variety of teachers.

The diversity of these schools was very limited. Most of the students came from similar church backgrounds and were probably from similar social-economic levels of society. One teacher mentioned that it did not keep students from coming to their school based on their I.Q. However, in the next sentence she went on to say that their school had a high, medium, and low track for students. Another words, even if there was some diversity of ability in the school, the class rooms themselves were very homogenous. Race was not a factor examined in this study although racial diversity in most of these schools was probably somewhat limited.

The following chart was compiled as the researcher went over the packets of data collected from each school. If there was any evidence that pointed to the qualities on the chart, the researcher checked that category for the school. The research used the overall 
data from the observation sheets, the interviews, and the administrative survey to compile this chart.

\section{School Structures Summary}

\begin{tabular}{|c|c|c|c|c|c|c|c|c|c|c|c|c|c|c|c|c|c|c|}
\hline $\begin{array}{c}\mathrm{S} \\
\mathbf{C} \\
\mathbf{H} \\
\mathbf{O} \\
\mathbf{O} \\
\mathbf{L} \\
\\
\text { \#'S }\end{array}$ & 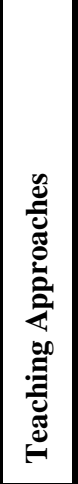 & 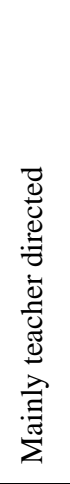 & 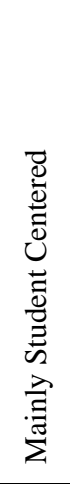 & 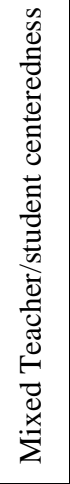 & 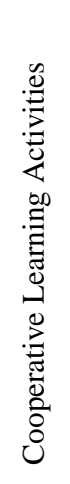 & 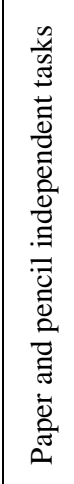 & 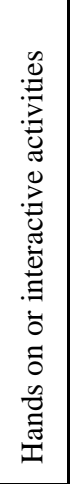 & 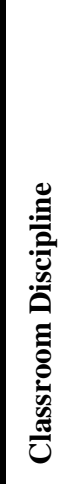 & 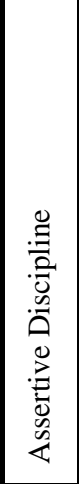 & 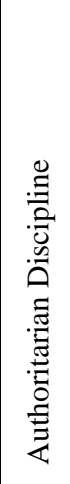 & 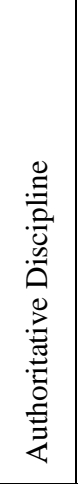 & 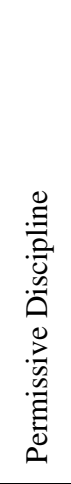 & 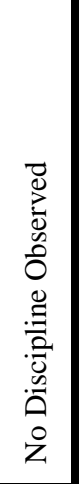 & 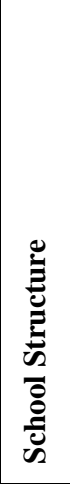 & $\begin{array}{l}\text { 号 } \\
\text { 䔍 } \\
\text { 邑 }\end{array}$ & 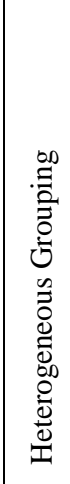 & 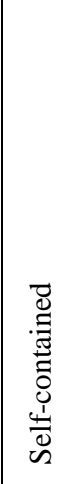 & 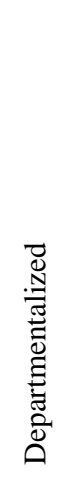 \\
\hline 1 & & $X$ & & & & $\mathbf{X}$ & & & & & $\mathbf{X}$ & & & & & & $\mathbf{X}$ & \\
\hline 2 & & $\mathbf{X}$ & & & $\mathbf{X}$ & $\mathbf{X}$ & $\mathbf{X}$ & & & $X$ & & & & & & & & $\mathbf{X}$ \\
\hline 3 & & $\mathbf{X}$ & & & $\mathbf{X}$ & $\mathbf{X}$ & & & & & & $\mathbf{X}$ & & & & & & $\mathbf{X}$ \\
\hline 4 & & & & & $\mathbf{X}$ & & & & & & & $\mathbf{X}$ & & & & & & $\mathbf{X}$ \\
\hline 5 & & $\mathbf{X}$ & & & & $\mathbf{X}$ & & & $\mathbf{X}$ & & & & & & & & & $\mathbf{X}$ \\
\hline 6 & & $\mathbf{X}$ & & & & $\mathbf{X}$ & & & & & $\mathbf{X}$ & & & & & & $\mathbf{X}$ & \\
\hline 7 & & $\mathrm{X}$ & & & $\mathbf{X}$ & $X$ & & & & & $\mathbf{X}$ & & & & $\mathbf{X}$ & & $\mathbf{X}$ & \\
\hline 8 & & $\mathbf{X}$ & & & $\mathbf{X}$ & $\mathbf{X}$ & & & & $X$ & & & & & & & & $\mathbf{X}$ \\
\hline 9 & & $\mathbf{X}$ & & & & & & & & & & & $\mathbf{X}$ & & & & & $\mathbf{X}$ \\
\hline 10 & & $\mathbf{X}$ & & & $\mathbf{X}$ & & $\mathbf{X}$ & & & & $\mathbf{X}$ & & & & & & & $\mathbf{X}$ \\
\hline 11 & & $\mathbf{X}$ & & & & $\mathbf{X}$ & & & & $X$ & & $\mathbf{X}$ & & & & & $\mathbf{X}$ & \\
\hline 12 & & $\mathbf{X}$ & & & $\mathbf{X}$ & $\mathbf{X}$ & & & & $X$ & & & & & $\mathbf{X}$ & & $\mathbf{X}$ & \\
\hline 13 & & $\mathbf{X}$ & & & & $\mathbf{X}$ & & & & & $\mathbf{X}$ & & & & & & $\mathbf{X}$ & \\
\hline 14 & & $\mathbf{X}$ & & & $\mathbf{X}$ & $\mathbf{X}$ & & & & & $\mathbf{X}$ & & & & & & & $\mathbf{X}$ \\
\hline 15 & & $\mathbf{X}$ & & & & $\mathbf{X}$ & & & & & & & $\mathbf{X}$ & & & & $\mathbf{X}$ & \\
\hline 16 & & $\mathbf{X}$ & & & & $\mathbf{X}$ & & & & & $\mathbf{X}$ & & & & & $\mathbf{X}$ & & $\mathbf{X}$ \\
\hline 17 & & $\mathbf{X}$ & & & $\mathbf{X}$ & $\mathbf{X}$ & & & & $X$ & & $\mathbf{X}$ & & & & & & $\mathbf{X}$ \\
\hline 18 & & $\mathbf{X}$ & & & $\mathbf{X}$ & $\mathbf{X}$ & & & & & & & $\mathbf{X}$ & & $\mathrm{X}$ & & & $\mathbf{X}$ \\
\hline
\end{tabular}


School Structures Summary Continued

\begin{tabular}{|c|c|c|c|c|c|c|c|c|c|c|c|c|c|c|c|}
\hline $\begin{array}{l}\mathbf{S} \\
\mathbf{C} \\
\mathbf{H} \\
\mathbf{O} \\
\mathbf{O} \\
\mathbf{L} \\
\text { \#'S }\end{array}$ & 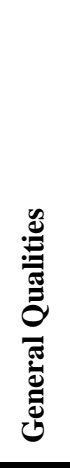 & 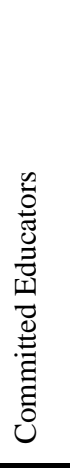 & 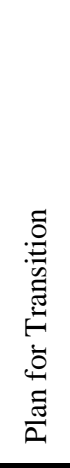 & 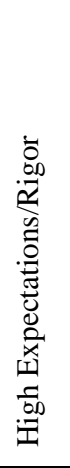 & 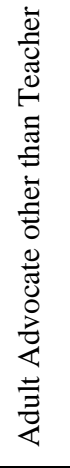 & 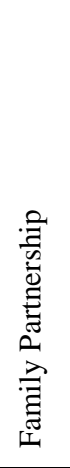 & 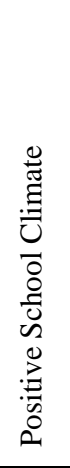 & 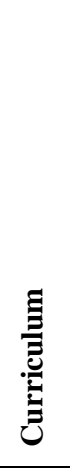 & 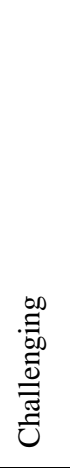 & 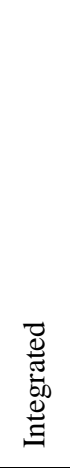 & 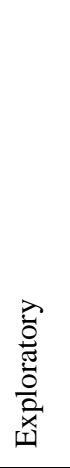 & 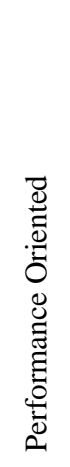 & 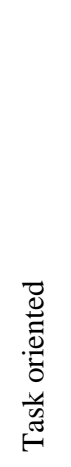 & 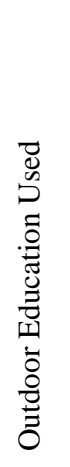 & 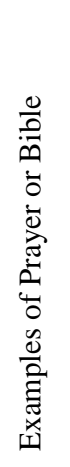 \\
\hline 1 & & $\mathbf{X}$ & & & & $\mathbf{X}$ & $\mathbf{X}$ & & & & & $\mathbf{X}$ & & & $\mathbf{X}$ \\
\hline 2 & & $\mathbf{X}$ & $\mathbf{X}$ & & & $\mathbf{X}$ & & & & & & $\mathbf{X}$ & & & $\mathbf{X}$ \\
\hline 3 & & $\mathbf{X}$ & $\mathbf{X}$ & & & $\mathbf{X}$ & $\mathbf{X}$ & & & & & $\mathbf{X}$ & & & $\mathbf{X}$ \\
\hline 4 & & $\mathbf{X}$ & & & & $\mathbf{X}$ & $\mathbf{X}$ & & & & & $\mathrm{X}$ & & & $\mathbf{X}$ \\
\hline 5 & & $\mathbf{X}$ & $\mathbf{X}$ & & & $\mathbf{X}$ & $\mathbf{X}$ & & & & $\mathbf{X}$ & $\mathbf{X}$ & & & $\mathbf{X}$ \\
\hline 6 & & $\mathbf{X}$ & & & & $\mathbf{X}$ & $\mathbf{X}$ & & & & $\mathbf{X}$ & $\mathbf{X}$ & & & $\mathbf{X}$ \\
\hline 7 & & $\mathbf{X}$ & $\mathrm{X}$ & & & $\mathbf{X}$ & $\mathbf{X}$ & & & & & $\mathrm{X}$ & & & $\mathbf{X}$ \\
\hline 8 & & $\mathbf{X}$ & $\mathbf{X}$ & $\mathbf{X}$ & & $\mathbf{X}$ & & & & & & $\mathbf{X}$ & & & $\mathbf{X}$ \\
\hline 9 & & $\mathbf{X}$ & & & & $\mathbf{X}$ & $\mathbf{X}$ & & & & & $\mathbf{X}$ & & & $\mathbf{X}$ \\
\hline 10 & & $\mathbf{X}$ & & & & $\mathbf{X}$ & $\mathbf{X}$ & & & & & $\mathrm{X}$ & & & $\mathbf{X}$ \\
\hline 11 & & $\mathbf{X}$ & $\mathbf{X}$ & & & $\mathbf{X}$ & & & & & & $\mathbf{X}$ & & & $\mathbf{X}$ \\
\hline 12 & & $\mathbf{X}$ & $\mathbf{X}$ & & & $\mathbf{X}$ & $\mathbf{X}$ & & & & & $\mathbf{X}$ & & & $\mathbf{X}$ \\
\hline 13 & & & $\mathbf{X}$ & & & $\mathbf{X}$ & $\mathbf{X}$ & & & & & $\mathbf{X}$ & & & $\mathbf{X}$ \\
\hline 14 & & $\mathbf{X}$ & $\mathbf{X}$ & & & $\mathbf{X}$ & $\mathbf{X}$ & & & & & $\mathbf{X}$ & & & $\mathbf{X}$ \\
\hline 15 & & $\mathbf{X}$ & $\mathbf{X}$ & & & $\mathbf{X}$ & $\mathbf{X}$ & & & & & $\mathbf{X}$ & & & \\
\hline 16 & & & & $X$ & & & $\mathbf{X}$ & & $\mathbf{X}$ & & & $\mathrm{X}$ & & & \\
\hline 17 & & & $\mathbf{X}$ & & $\mathbf{X}$ & $\mathbf{X}$ & & & & & & $\mathbf{X}$ & & & \\
\hline 18 & & $\mathbf{X}$ & $\mathrm{X}$ & & & $\mathbf{X}$ & $\mathbf{X}$ & & & & & $\mathrm{X}$ & & & \\
\hline
\end{tabular}


These charts demonstrate that even though these are different schools in different locations, overall they are very similar in structure and function. The patterns that seem most obvious are that the schools are teacher-centered and performance oriented. The schools all seem to share dedicated educators that are very devoted to their schools. The structures of these schools seem to be very traditional with either self-contained or departmentalized settings. Family partnership and positive school climate are evident in all of these schools.

Many of the key elements of model middle schools were not evident in the data collected. Most of the schools did not have a specific staff person to act as advocate for the students other than the teachers and principals. There was very little evidence of integrated, exploratory, task oriented teaching going on in the classrooms observed. The classrooms appeared to be very teacher-centered with a few schools using limited cooperative learning activities. 


\section{SUMMARY - CONCLUSIONS AND RECOMMENDATIONS}

The focus of this study has been in several areas. First of all, its purpose was to analyze the literature on middle grade structures for schools. Secondly, its purpose was to examine the structures of Christian schools. Thirdly, its purpose was to look at the patterns found in the eighteen Christian schools studied. Finally, its purpose was to examine the implications for Christian schools desiring to provide an excellent educational experience for all of their students.

\section{Conclusions from the Literature Review}

One thing was abundantly clear from the literature review; adolescence is a unique time developmentally in the life of a student and calls for special consideration when planning the educational structures and experiences of students. The literature pointed out that the extreme physical changes that children go through during this time period can also cause psychological changes. It also is clear that this is a time when children are struggling to define themselves morally. Behavior at this age is often up and down and at times extremely difficult to deal with in a calm manner. The literature also documents that going through major changes in schools during this time period can add stress to an already stress-filled time period. This stress can lead to major rebellion and drops in personal motivation.

The middle school model was developed in order to address the unique qualities of this period of development. This movement desired committed educators who had a shared vision of high expectations for this age group. It called for things like an adult advocate for every student, family and community partnerships, and positive school climates. It was believed that these things could be achieved by providing challenging, 
integrative, and exploratory curriculums. Varied teaching and learning approaches in which teachers and administrators have creative freedom to allow the students to help design the curriculum was also considered an important aspect of teaching students at this level. Middle schools, according to the literature, need to be committed to capturing the curiosity of students by using a variety of methods such as cooperative learning, outdoor education, and any other method that makes learning active, hands on, and relevant. Task oriented schools seem to experience less of a motivational and achievement drop than those schools that were more performance oriented.

An emphasis on teaming students into smaller groups where it would be easier to form strong relationships and trust is also important to middle school structures. It is important to have heterogeneous teams rather than ability tracked classes in middle schools.

The most important aspect of the educational experience at this level, according to the research, is the teacher. In order to provide excellent schooling at this level, it is important to have teachers who are specifically trained to deal with the unique qualities of the learners of this age and development. The evidence in the literature indicates that regardless of structure or method, it is the dedicated, effective teacher that makes the difference. Teachers at this level should be called to work with kids of this age. They need to understand where the students are developmentally, and they need to be experts in their subject areas. The importance of preparation specifically to educate children at this level is reflected in the effort of many states to now specifically certify teachers to teach in the middle grades. 
All of the ideas for mid-level education sound great on paper, but in reality many of the ideals of this movement have been extremely difficult to implement. In public school or private school very few have implemented interdisciplinary teams, flexible scheduling, or a truly exploratory curriculum. It becomes very difficult to assess the effectiveness of middle school structures when very few schools have actually been able to successfully implement them.

\section{Christian School Structures}

Christian schools were formed out of a reaction to changes in society and public education. The schools in the study as well as many other Christian schools that the researcher has had contact with are structured very traditionally. These schools are financed and populated by students who for the most part are from middle class homes. The schools tend to be very teacher-centered and performance oriented partially because that is the traditional structure that parents experienced when they were in school and therefore they feel most comfortable with it.

The significant difference for Christian schools lies in the similarity of moral practices between the home, church, and school. Teachers can spontaneously model their personal beliefs in Christianity and can demonstrate a worldview that is in harmony with the worldview of the parents and the church. Christian schools can control the type of students that they accept into their student body which often leads to a very homogeneous setting. Many parents see this as a safer setting for their children to be in during their formative years.

Christian schools also often share the natural advantage of being smaller. Teachers have the privilege of watching their students grow up from preschool through 
graduation. The stress of actually changing from a small neighborhood elementary to a larger middle school setting is avoided in most Christian schools. The stress of going to an unfamiliar place with unfamiliar teachers is avoided because often the entire school is housed in one building. The other advantage shared by Christian schools is parental involvement. According to research, middle class parents tend to be more involved in the education of their children. When that is combined with the fact that they are paying tuition for their children, it often causes them to be much more involved in volunteering and serving on advisory committees for their schools.

Some criticize Christian schools as not being that much different from their public counterparts. Other than the freedom to pray and discuss spiritual issues publicly, and the absence of evolution theories in science education, there are very few actual differences in teaching methods or curriculums. In comparing the Life in the Three Sixth Grades, a study done by Lounsbury and Johnston in 1988, to the study of life in Christian middle school done in this report, a typical day in both settings seemed quite similar.

\section{Patterns Found in the Eighteen Schools Studied}

Many of the eighteen schools studied were missing certain components of the ideal middle school model. First of all, certain elements of the middle school model were difficult to discern from one day of observation. For example, the emphasis on health and fitness was not demonstrated by any of the schools, however that does not mean that there is no emphasis in that area, it just was not visible on the day of the study. Another element that was lacking was the adult advocate for every child. The budget of many Christian schools probably makes it difficult to fund such a position. Another area that was difficult to discern from the data was high expectations or rigor. In a sense, it is 
there because Christian schools tend to be college preparatory in nature. Christian schools also tend to do very well on achievement tests. However, in just looking at a single day in a Christian school, it was difficult to pinpoint specifically. Even in the interviews of the teacher or student shadowed, a sense of academic rigor did not come to light.

One area that was definitely lacking in the schools studied was studentcenteredness. Teachers were definitely guiding the education process. It seemed clear that there was not much freedom in terms of curriculum development. Students seemed to have very little voice in how they were educated. Along these same lines, there was very little evidence of integrated or exploratory learning. Performance oriented learning was pervasive over task oriented learning. Many Christians do not hold a very optimistic view of man. Due to this, there is much emphasis in control and training of children because it is believed if they are left to their own devices they will not make wise choices. This causes reluctance for administrators and teachers to relinquish too much control.

While Christian schools were missing key elements for ideal middle schools in some areas, they were very strong in other areas. For example, Christian schools are very strong in having committed educators. Many of the educators in the study were parents of students in the school. Many of them stated that they felt called to teach in their particular school. Most of the schools appear to have a unique vision for middle school and had programs in place to ease the transition from elementary to middle school easier. Most of the school seemed to have a positive school climate. In the end of the day 
reflections of the researcher, all of them had positive things to say about their experience and about the atmosphere of the school they were observing.

In examining the Chart of Activities (Appendix K), it is clear that all of the schools had a variety of things happening during the day. None of the schools centered on teacher lecture for the whole day, but rather there was a mix of whole class activities and independent written activities. The use of active, hands on learning activities on the days of the particular observations was limited. Many of the schools used at least a limited amount of cooperative learning activities.

The variety of discipline styles and types of misbehaviors observed were similar to what was found in studies of public schools. Again it is evident that just being a Christian student in a Christian school does not drastically change the typical behavior of kids at this age. It was quite evident in the study that they responded well when a teacher was clearly in charge and that things were chaotic when a teacher did not take charge.

\section{Implications for Christian Schools}

It is evident from the research and from the schools studied that true implementation of the ideal middle school model is extremely difficult to do. It takes a shared vision by parents, teachers, administrators, and students in order to be able to even become close to doing it. Christian schools have many advantages in dealing with students in the middle grades, and they are doing many things right.

It is the administrators of these schools responsibility to make sure that their teachers are properly trained in dealing with middle school. Enabling teachers to take graduate classes in the field, or offering in-services that are directed at preparing teachers to deal with middle school students is important. Too often middle school gets little 
attention while high school and elementary schools are the stars of the system.

Administrators need to catch the vision of wanting to create an educational experience for the middle grades that is rich and unique.

It is also important that the administration and school boards be willing to grant creative freedom to the teachers and students. It is very easy for many Christian schools to fall into the trap of doing things the way they have always been done. The idea of changing to new methods and ideas goes against the grain. However, if the administration hires competent teachers that have experience and training in dealing with middle school education, then they need to be given the trust and the freedom to do it in a manner that will be best for capturing the interest and the energy of this age level. If the schools in this study represent the typical Christian school across the country, then it does not appear that Christian schools are prepared to hire and effectively use the new breed of teacher that is being certified specifically to deal with middle school education. Schools need to be willing to redesign their structures to better fit the middle school model.

Public schools are struggling to maintain the ideals of the middle school model as the battle over standard based education rages on. Christian schools have much more freedom to decide what to teach and how to teach it right now than do many public schools. If Christian schools are to remain competitive in this economy, they are going to have to demonstrate that they are truly providing an alternative to other schools that is excellent and unique.

Christian schools also need to be more open to examination of their practices by researchers. For too long many schools have had closed doors to outside interference or study. Other researchers need to look at the practices of Christian schools and their 
effects on things like achievement, character education, and leadership development.

One of the important tenets of Christianity is continual self-examination in order to attempt to glorify God in everything that is done. This same self-examination of Christian schools should be happening throughout the country to guarantee that Christian education is doing its best to provide the very best education possible for its constituents. 
APPENDIX A

Checklist of Middle School Practices

\begin{tabular}{|c|c|c|c|c|c|c|c|c|c|c|c|c|c|c|c|}
\hline $\begin{array}{l}\mathbf{S} \\
\mathbf{C} \\
\mathbf{H} \\
\mathbf{O} \\
\mathbf{O} \\
\mathbf{L} \\
\text { \#'S }\end{array}$ & 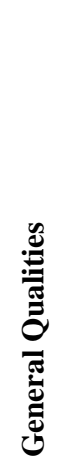 & 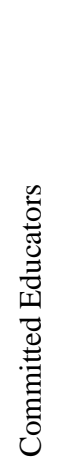 & 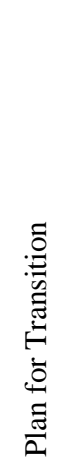 & 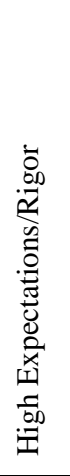 & 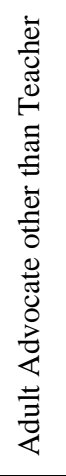 & 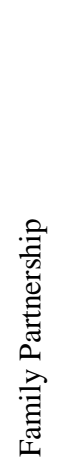 & 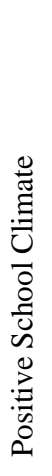 & 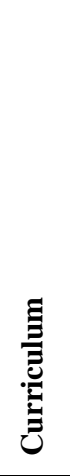 & 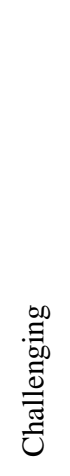 & 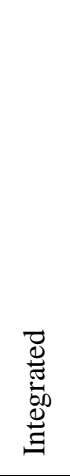 & 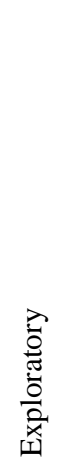 & 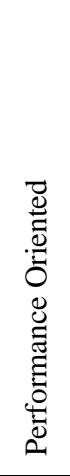 & 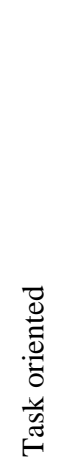 & 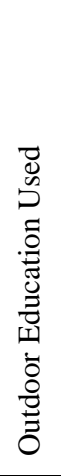 & 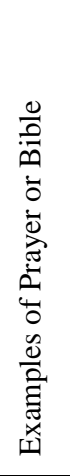 \\
\hline 1 & & & & & & & & & & & & & & & \\
\hline 2 & & & & & & & & & & & & & & & \\
\hline 3 & & & & & & & & & & & & & & & \\
\hline 4 & & & & & & & & & & & & & & & \\
\hline 5 & & & & & & & & & & & & & & & \\
\hline 6 & & & & & & & & & & & & & & & \\
\hline 7 & & & & & & & & & & & & & & & \\
\hline 8 & & & & & & & & & & & & & & & \\
\hline 9 & & & & & & & & & & & & & & & \\
\hline 10 & & & & & & & & & & & & & & & \\
\hline 11 & & & & & & & & & & & & & & & \\
\hline 12 & & & & & & & & & & & & & & & \\
\hline 13 & & & & & & & & & & & & & & & \\
\hline 14 & & & & & & & & & & & & & & & \\
\hline 15 & & & & & & & & & & & & & & & \\
\hline 16 & & & & & & & & & & & & & & & \\
\hline 17 & & & & & & & & & & & & & & & \\
\hline 18 & & & & & & & & & & & & & & & \\
\hline
\end{tabular}


APPENDIX A CONTINUED

Checklist of Middle School Practices

\begin{tabular}{|c|c|c|c|c|c|c|c|c|c|c|c|c|c|c|c|c|c|c|}
\hline $\begin{array}{c}\mathbf{S} \\
\mathbf{C} \\
\mathbf{H} \\
\mathbf{O} \\
\mathbf{O} \\
\mathbf{L} \\
\text { \#'S }\end{array}$ & 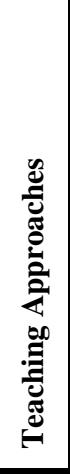 & 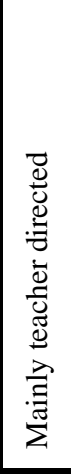 & 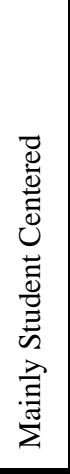 & 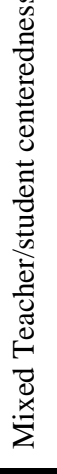 & 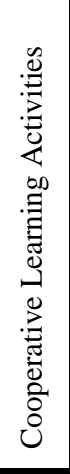 & 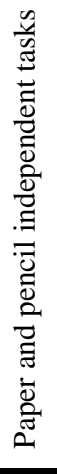 & 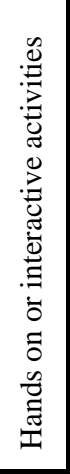 & 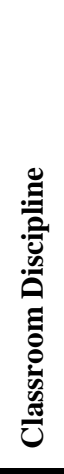 & 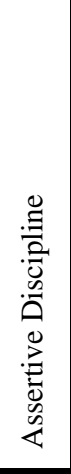 & 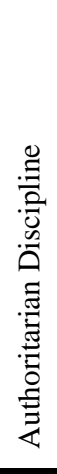 & 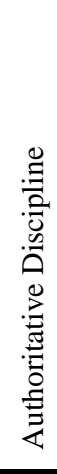 & 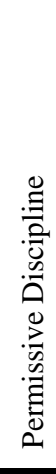 & 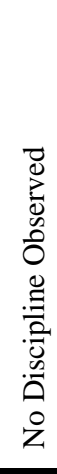 & 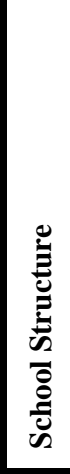 & 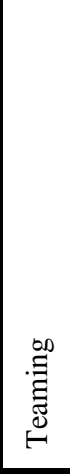 & 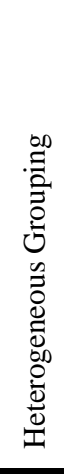 & 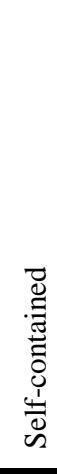 & 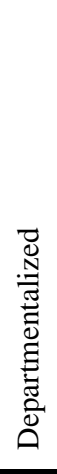 \\
\hline 1 & & & & & & & & & & & & & & & & & & \\
\hline 2 & & & & & & & & & & & & & & & & & & \\
\hline 3 & & & & & & & & & & & & & & & & & & \\
\hline 4 & & & & & & & & & & & & & & & & & & \\
\hline 5 & & & & & & & & & & & & & & & & & & \\
\hline 6 & & & & & & & & & & & & & & & & & & \\
\hline 7 & & & & & & & & & & & & & & & & & & \\
\hline 8 & & & & & & & & & & & & & & & & & & \\
\hline 9 & & & & & & & & & & & & & & & & & & \\
\hline 10 & & & & & & & & & & & & & & & & & & \\
\hline 11 & & & & & & & & & & & & & & & & & & \\
\hline 12 & & & & & & & & & & & & & & & & & & \\
\hline 13 & & & & & & & & & & & & & & & & & & \\
\hline 14 & & & & & & & & & & & & & & & & & & \\
\hline 15 & & & & & & & & & & & & & & & & & & \\
\hline 16 & & & & & & & & & & & & & & & & & & \\
\hline 17 & & & & & & & & & & & & & & & & & & \\
\hline 18 & & & & & & & & & & & & & & & & & & \\
\hline
\end{tabular}




\section{APPENDIX B \\ General Directions for the Data Gathering Directions}

1) Give the letter to your administrator along with the survey the first day that you observe.

2) Plan to do the observation the first day that you are there. It is important that you record your impressions without being influenced by things that happened on previous days.

3) On the observation record the terms at the top mean the following:

a. Specific behavior - what exactly are the class and the teaching doing at that moment.

b. Environment - physical observations such as it is very quiet, its warm in here, its noisy, the lights are out, etc.

c. Impression - your take on what is going on. For example, the students are all listening quietly, or they seem bored, or they are all fidgeting, or they seem engaged, or they are all actively participating in the group activity.

4) Be sure to interview the teacher at the end of the day.

5) Be sure to record your impressions of the day.

6) Mail the folder to me with the needed information in it. 


\section{APPENDIX C Administrative Letter}

Teresea Baumann

1177 Arkansas Drive

Xenia, Ohio 45385

December 2, 2003

Dear Administrator:

My name is Teresea Baumann, and I am presently working on a thesis project in order to complete my master's degree at Cedarville University in Cedarville, Ohio. I also teach sixth grade at Dayton Christian Schools. For my project I am doing a qualitative study of the methods of organizing and teaching middle grades in a cross section of Christian schools.

I have asked Cedarville undergraduate students to assist me in the gathering of data for this project. All Cedarville undergraduate education majors are required to spend a week observing and assisting in a Christian school of their choice. Many of these students choose to do this observation in their home town. Since Cedarville Students come from all over the country to attend Cedarville, having these students gather data for me as one the days of their observation should allow me to gather a varied cross section of data.

All information gathered by these students will be confidential. In the reporting of the findings of the study, no names of schools will be stated. All that will be given will be size and organization of the school.

The Cedarville students have been asked to be assigned a random student or a teacher that they can shadow for the day. Throughout the day they will be noting what the student or teacher is doing at 5-7 minute intervals. For the quality of the research, it would be best that the student or teacher not know that the Cedarville student is shadowing them. At the end of the day, the Cedarville student will need to have around twenty minutes to interview the teacher that they have been shadowing. If they have been shadowing a student, they will be sending home a permission slip to the parent of the student at the end of the day to ask if they may briefly interview the student the next day. The goal of the research will be to compare and contrast the life of a middle school student in a Christian school to similar studies that have been done on public school students.

In order to understand the types of schools used in the research, I would like the administrator of the middle grades to fill out the attached survey. If your school is interested in the findings of my study, I would be willing to send you a copy of my completed thesis.

Very little data on the handling of middle school students in Christian schools exists. This is an exciting opportunity to examine practices in a number of different schools. I would just like to thank you for being willing to participate in this study. I also understand if you do not wish to participate in this study. If you have any additional questions about the nature of the study, please feel free to email me at tbaumann@daytonchristian.com.

Sincerely yours,

Mrs. Teresea L. Baumann 


\section{APPENDIX D \\ Administrative Survey \\ Administrative Survey}

Please answer the following questions about your school.

1. Which statement best describes the size of your school?

a. Small - less than 100 students

b. Medium - between 100 to 400 students

c. Large - more than 400 students

2. Which statement describes the grade levels served by your school?
a. Kindergarten -6
b. Kindergarten -8
c. Kindergarten -12
d. Grades 5-8
e. Grades 6-8
f. Grades $7-12$
g. Other

3. Which of the following statements would describe the level of diversity in your school?
a. More than $90 \%$ white, less than $10 \%$ non-white
b. $80 \%$ white, $20 \%$ non-white
c. $70 \%$ white, $30 \%$ non-white
d. $50 \%$ white, $50 \%$ non-white
e. $40 \%$ white, $60 \%$ non-white
f. Less than $30 \%$ white, more than $70 \%$ non-white

4. Which of the following statements would best describe your school structure for the middle grades?
a. Grades K- $6^{\text {th }}$ are considered elementary grades and grades 7-12 are considered secondary grades
b. Grades $\mathrm{K}-4^{\text {th }}$ are elementary, grades 5-8 are middles school, grades 9-12 are high school
c. Grades K-5 ${ }^{\text {th }}$ are elementary, grades 6-8 are middle school, and grades 9- 12 are high school
d. Grades K-8 ${ }^{\text {th }}$ are elementary, grades 9-12 are high school
e. Other

5. Do all grades of your school meet in the same building? Circle one. Yes or no.
6. If all of your grades do not meet in one building, how are they divided among buildings?

7. How many years has your school been in existence? 
8. Which of the following statements best describe the assignment of teachers in your school?

a. Teachers may be assigned to teach classes in a variety of grades from 6$12^{\text {th }}$ grade.

b. Teachers are only assigned to teach grades 9-12 or are only assigned to teach grades 6-8.

c. Teachers in grades 5-8 have self-contained classrooms in which the students do not switch teachers for various classes

9. How many of your teachers in the middle grades have special training of licensure in that level of teaching?

a. Almost all have specific training

b. Some have specific training

c. Few have specific training

d. None have specific training

10. Which statement best describes how your school handles the transition from elementary grades to secondary grades?

a. Students are gradually introduced to have more than one teacher and specific things are done to help them adjust.

b. Students go from having one teacher to having several without much specific preparation for that change.

11. If you chose (a.) in number 10, briefly describe some of the things that your school does to ease the adjustment to multiple teachers and classes.

12. What is the overall attitude of the faculty toward the middle grades in your school?

13. Is there anything that you personally would like to see changed about the way that your school handles the middle grades?

14. Is there anything that your school does for students in the middle grades that you feel makes your program for those grades particularly strong?

Thank you so much for taking the time to fill out this survey. 


\section{APPENDIX E \\ Research Procedures for Shadowing a Teacher or a Student Research Procedures for Shadowing a Teacher}

1. Ask your administrator to be assigned to one teacher for the whole day.

2. Follow this teacher throughout the day. Do not tell them that you are recording what they are doing at intervals all day to help the validity of your observations.

3. Be willing to help them with tasks, but stress that it is important that you be in the room observing for the entire day. Try to avoid doing tasks that take you out of the classroom for large blocks of time.

4. Observe the teacher even during his or her preparation periods and lunch break.

5. Write down what the teacher is doing, the environment, and your impression of what is going on every 5 to 7 minutes.

6. At the end of the day, interview the teacher.

7. At the end of the day, be sure to reflect on your impressions of the day. Fill out the end of the day survey for yourself.

\section{Research Procedures for Shadowing a Student}

1. Ask to randomly be assigned a student that you can shadow for the day.

- If students are numbered in a class, choose a random number. If they are not numbered than choose a letter of the alphabet, and take the first student whose last name starts with that letter.

- Ask the administrator or school secretary to help with this rather than the teacher.

- If possible, for the quality of the research, it is better if the teacher(s) do not know that you are specifically shadowing a student.

- $\quad$ Be sure that it is okay to pull the student out for a 10-20 minute end of the day survey. Find out a good place to use to conduct your interview.

2. Get a copy of that students schedule for the day and directions to where you will first find them.

3. Discretely follow them throughout the day. Jot down observations of what they are doing every 5 to 7 minutes. This includes following them to special classes and to the cafeteria at lunch.

4. If students ask why you are there, just tell them that you are doing observations in a Christian school for your university requirements.

5. You should still be able to do tasks for the teacher. Just remember to stop and record the specific behavior, environment, and your impression every 5 to 7 minutes.

6. Near the end of the day, ask to take the student you have been shadowing out of class for an interview.

7. At the end of the day, be sure to reflect on your impressions of the day. Fill out the end of the day survey for yourself. 


\section{APPENDIX F \\ Observation Form \\ Observation Form}

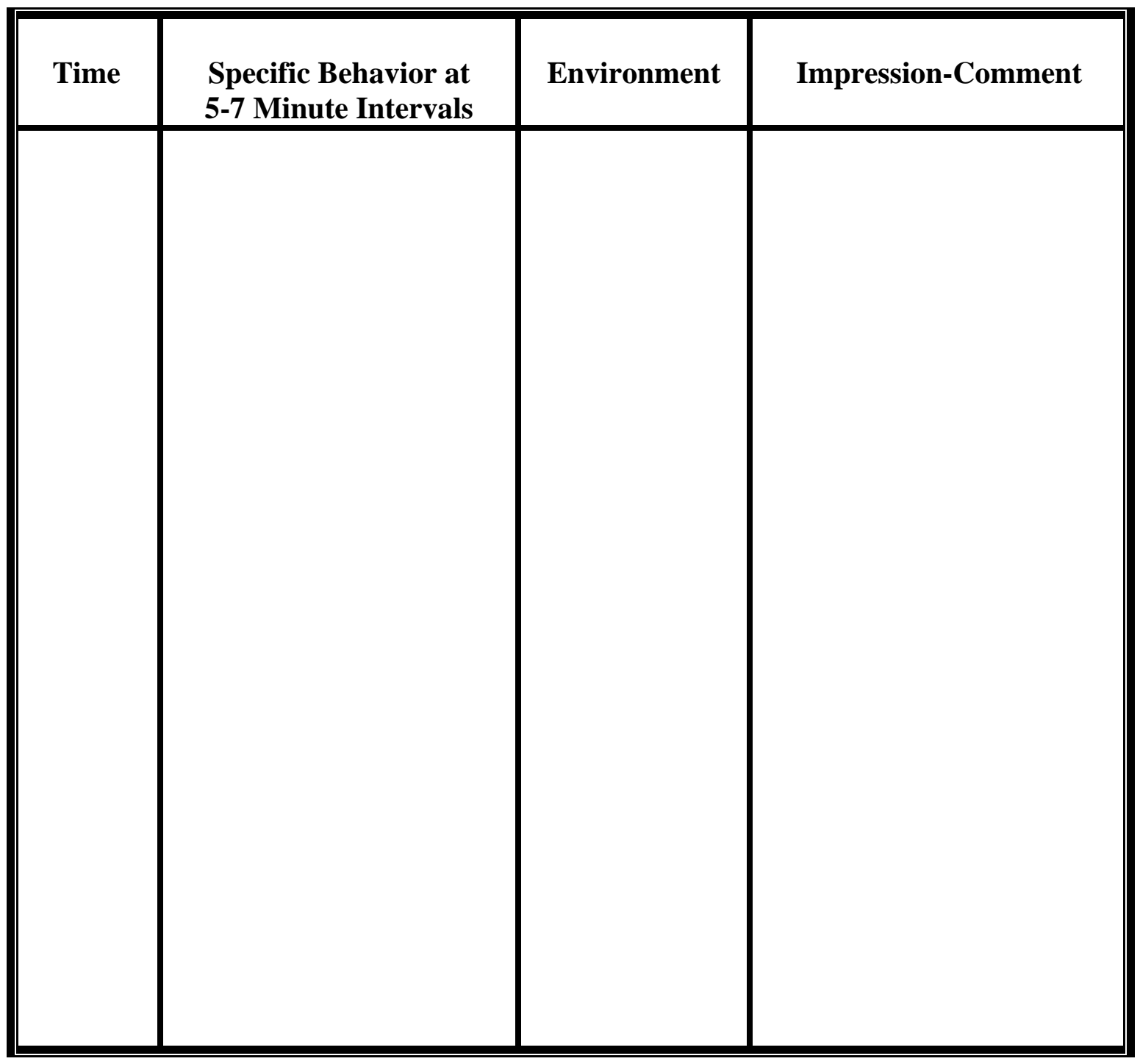




\section{APPENDIX G \\ Permission Slip \\ Permission Slip}

Dear Parent,

Your son or daughter has randomly been chosen to participate in a qualitative study of how middle grade education is handled in Christian schools. A Cedarville University student who is observing in your school this week would like permission to briefly interview your son or daughter about his or her middle school experience. The interview will be very general and will only take 10-15 minutes. The student's name will not be included with the data from the interview. The name of the school will not be used either in this study.

Thank you for your help in this matter.

Yours in Christ,

Teresea Baumann

I give permission for my son or daughter to be interviewed by a Cedarville University student.

I do not want my son or daughter to be interviewed.

\section{Parent or Guardian Signature}

Please return this slip to school tomorrow. 


\section{Appendix H \\ Teacher Interview \\ Teacher Interview at the End of the Day}

1. Tell me about yourself.

2. How did you decide to become a teacher?

3. What do like best about this school?

4. How do you feel about the quality of instruction that students receive at this school?

5. Do you work with other teachers in the planning of instruction for the students?

6. Do you allow the students to have any control over what they will learn about in your class?

7. Do you feel that most students have an adult at the school that they can talk to if they have problems or concerns to deal with?

8. How do feel about the overall discipline at your school?

9. How do you feel about the involvement and support of the parents at this level of the school?

10. If there were anything about your school that you could change, what would it be?

11. How do you feel about the extracurricular activities that are offered for students in middle grades at your school?

12. Do you have any additional comments that you would like to make? 


\section{APPENDIX I \\ Student Interview \\ Student Interview at the End of the Day}

1. Tell me about yourself.

2. What is the best thing about your school?

3. Is there anything about your school that you would change?

4. How do you feel about the quality of education that you receive at your school?

5. If you have a problem, do you feel that there is someone in your school that you can go to for help?

6. Do you feel like you are active in the activities of your classroom?

7. Does your school provide sports, clubs, or activities after school or on weekends?

8. How do you feel about the overall discipline of your school?

9. How do the students in your school treat each other?

10. What do you think makes your school different from other schools in the area?

11. Do you have any additional comments about your school? 


\section{APPENDIX $J$ \\ End of Day Researcher Reflections End of the Day Reflections of the Researcher}

1. What is your overall impression of the day?

2. Was the day different than you expected?

3. Did you go to this school when you were in the middle grades? If so, what has changed or what has not changed?

4. What is your feeling about the kind of education students are receiving in the middle grades at this school?

5. What did you observe about the attitudes of the students and teachers at the school?

6. What impression did you get about the atmosphere at the school?

7. Do you have any additional comments about the day? 
APPENDIX K

Chart of Activities Observed

Chart of Activities Observed

\begin{tabular}{|c|c|c|c|c|c|c|c|c|c|}
\hline & 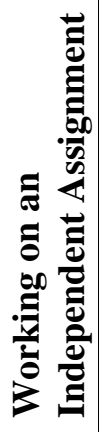 & 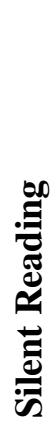 & 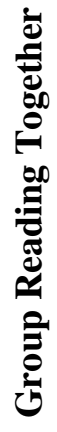 & 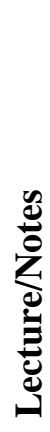 & 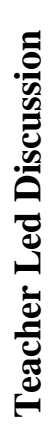 & 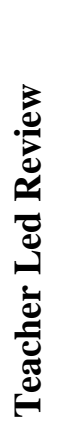 & 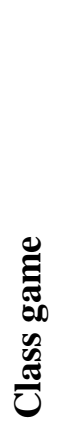 & حُ & 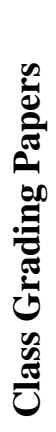 \\
\hline 1 & & & & & & & & & \\
\hline 2 & & & & & & & & & \\
\hline 3 & & & & & & & & & \\
\hline 4 & & & & & & & & & \\
\hline 5 & & & & & & & & & \\
\hline 6 & & & & & & & & & \\
\hline 7 & & & & & & & & & \\
\hline 8 & & & & & & & & & \\
\hline 9 & & & & & & & & & \\
\hline 10 & & & & & & & & & \\
\hline 11 & & & & & & & & & \\
\hline 12 & & & & & & & & & \\
\hline 13 & & & & & & & & & \\
\hline 14 & & & & & & & & & \\
\hline 15 & & & & & & & & & \\
\hline 16 & & & & & & & & & \\
\hline 17 & & & & & & & & & \\
\hline 18 & & & & & & & & & \\
\hline
\end{tabular}


Chart of Activities Continued

\begin{tabular}{|c|c|c|c|c|c|c|c|c|c|c|}
\hline & 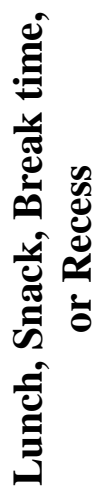 & 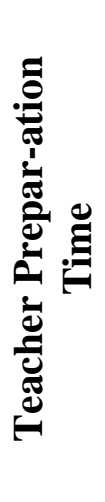 & 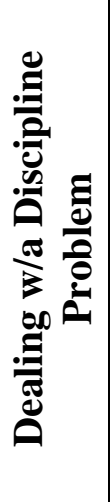 & 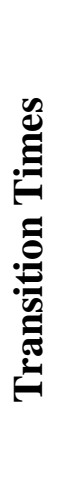 & 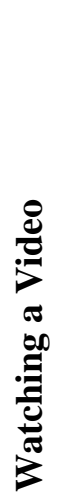 & 旁 & 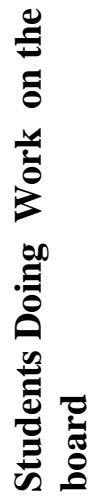 & 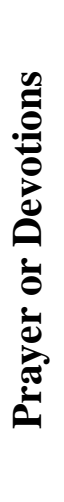 & 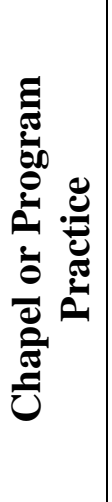 & 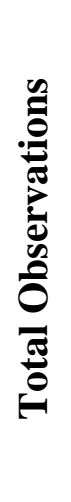 \\
\hline 1 & & & & & & & & & & \\
\hline 2 & & & & & & & & & & \\
\hline 3 & & & & & & & & & & \\
\hline 4 & & & & & & & & & & \\
\hline 5 & & & & & & & & & & \\
\hline 6 & & & & & & & & & & \\
\hline 7 & & & & & & & & & & \\
\hline 8 & & & & & & & & & & \\
\hline 9 & & & & & & & & & & \\
\hline 10 & & & & & & & & & & \\
\hline 11 & & & & & & & & & & \\
\hline 12 & & & & & & & & & & \\
\hline 13 & & & & & & & & & & \\
\hline 14 & & & & & & & & & & \\
\hline 15 & & & & & & & & & & \\
\hline 16 & & & & & & & & & & \\
\hline 17 & & & & & & & & & & \\
\hline 18 & & & & & & & & & & \\
\hline
\end{tabular}




\section{REFERENCES}

1. Knowles, T. \& Brown, D. (2000). What every middle school teacher should know. Portsmouth, NH: Heinemann NMSA, p.4.

2. Williamson, R. \& Johnston, J. (1999, May). Serious answers to parent/public middle school concerns. The Education Digest, 64 (9), 4-11.

3. Anderman, E., Maehr, M., \& Midgley, C. (1999). Declining motivation after the transition to middle school: schools can make a difference. Journal of Research and Development in Education, 32 (3), 131-145.

4. Williamson, R. \& Johnston, J. (1999, May). Serious answers to parent/public middle school concerns. The Education Digest, 64 (9), 4-11.

5. Carnegie Council on Adolescent Development. (1989). Turning Points: Preparing American youth for the $21^{\text {st }}$ century. New York: Carnegie Corporation.

6. Brockett, D. (1999). Re-Examining MIDDLE-SCHOOL REFORM. The Education Digest, 64 (6), 30-33.

7. Weilbacher, G. (2000). Is curriculum integration an endangered species? Middle School Journal, 33(2) 18-27.

8. Slavin, R.E. (1986). Best-evidence synthesis: an alternative to meta-analytic and traditional reviews. Educational Researcher, 15, (9), 5-11.

9. Knowles, T. \& Brown, D. (2000). What every middle school teacher should know. Portsmouth, NH: Heinemann NMSA, p. 47-48.

10. MacArthur, John (1997). The MacArthur Study Bible. Nashville, TN: Word Bibles, p. 260.

11. Knowles, T. \& Brown, D. (2000). What every middle school teacher should know. Portsmouth, NH: Heinemann NMSA, p. 49-50.

12. Schindler, C. (1987). Sowing for excellence. Whittier, CA: Association of Christian Schools International, p.10.

13. Schindler, C. (1987). Sowing for excellence. Whittier, CA: Association of Christian Schools International, p.157.

14. George, P., \& Alexander, M. (1993). The exemplary middle school. Fort Worth, TX: Harcourt College Publishers. 
15. Schurr, S. (1992). How to evaluate your middle school. Columbus, $\mathrm{OH}$ : National Middle School Association.

16. Knowles, T. \& Brown, D. (2000). What every middle school teacher should know. Portsmouth, NH: Heinemann NMSA, p. 200.

17. Lounsbury, J. \& Johnston, J. (1988) Life in the three $6^{\text {th }}$ grades. Reston, VA: National Association of Secondary School Principals.

18. Knowles, T. \& Brown, D. (2000). What every middle school teacher should know. Portsmouth, NH: Heinemann NMSA, p. 200.

19. Knowles, T. \& Brown, D. (2000). What every middle school teacher should know. Portsmouth, NH: Heinemann NMSA.

20. Atwell, N. (1998). In the middle: New understanding about writing, reading, and learning. $\left(2^{\text {nd }}\right.$ ed.). Portsmouth, $\mathrm{NH}$ : Heinemann.

21. Walley, C. \& Gerrick W.G. (1999). Affirming middle grades education. Boston, MA: Allyn and Bacon.

22. Knowles, T. \& Brown, D. (2000). What every middle school teacher should know. Portsmouth, NH: Heinemann NMSA.

23. Knowles, T. \& Brown, D. (2000). What Every Middle School Teacher Should Know. Portsmouth, NH: Heinemann NMSA.

24. Shoffner, M. \& Williamson, R. (2000). Facilitating student transitions into middle school. Middle School Journal, 31 (4), 47-51.

25. Lounsbury, J. \& Johnston, J. (1988) Life in the three $6^{\text {th }}$ grades. Reston, VA: National Association of Secondary School Principals.

26. Kohlberg, L. (1981). The philosophy of moral development: Moral stages and the idea of justice. San Francisco: Harper \& Row.

27. George, P., \& Alexander, M. (1993). The exemplary middleschool. Fort Worth, TX: Harcourt College Publishers.

28. Walley, C. \& Gerrick W.G. (1999). Affirming middle grades education. Boston, MA: Allyn and Bacon.

29. Williams, K. \& McGillicuddy-De Lisi, A. (2000) Coping Strategies in Adolescents. Journal of Applied Developmental Psychology, 20(4), 537-549.

30. Knowles, T. \& Brown, D. (2000). What Every Middle School Teacher Should Know. Portsmouth, NH: Heinemann NMSA. 
31. Carnegie Council on Adolescent Development. (1989). Turning Points: Preparing American youth for the $21^{\text {st }}$ century. New York: Carnegie Corporation.

32. Carnegie Council on Adolescent Development. (1989). Turning Points: Preparing American youth for the $21^{\text {st }}$ century. New York: Carnegie Corporation.

33. Knowles, T. \& Brown, D. (2000). What Every Middle School Teacher Should Know. Portsmouth, NH: Heinemann NMSA.

34. Berkowitz, J. \& Uline, C. A changing school culture: The case study of Galion Middle School. (1999). Columbus, OH: Ohio Department of Education.

35. Walley, C. \& Gerrick W.G. (1999). Affirming middle grades education. Boston, MA: Allyn and Bacon.

36. Weilbacher, G. (2000). Is curriculum integration an endangered species? Middle School Journal, 33(2) 18-27.

37. Elmore, R. (2000). Leadership for effective middle school practice. Phi Delta Kappan, 82 (4), 291-292.

38. Storz, M. \& Nestor, K. (2003). Insight into meeting standards from listening to the voices of urban students. Middle School Journal, 34 (4), 11-19.

39. Bandlow, R. (2001). The misdirection of middle school reform: Is a childcentered approach incompatible with achievement in math and science? The Clearing House, 75 (2), 69-73.

40. Hargreaves, A. \& Moore, S. (2000) Curricululm integration and classroom relevance: A study of teachers' practice. Journal of Curriculum and Supervision,15 (2), 89-112.

41. Gehlbach, H. \& Roeser, R. The middle way to motivating middle school students: avoiding false dichotomies. Middle School Journal, 33 (3), 39-46.

42. Malloy, W. \& Rayle, J. (2000) Using the comer process to create a successful middle school. Middle School Journal, 31 (5), 12-18.

43. Frost, R., Olson, E., \& Valiquette, L. The Wolf Pack: Power shared and power earned-building a middle school nation. Middle School Journal, 31 (5), 30-36.

44. Anderman, L.H., \& Midgley, C. (1997). Motivation and middle school students. In Judith L. Irvin (Ed.), What Current Research Says to the Middle Level Practitiioner, 41-48. 
45. Berkowitz, J. \& Uline, C. A changing school culture: The case study of Galion Middle School. (1999). Columbus, OH: Ohio Department of Education.

46. Lancaster, E. \& Rikard, G. (2002) Across the curriculum learning through movement. Middle School Journal, (33) 3, 28-33.

47. Lounsbury, J. \& Johnston, J. (1988) Life in the three $6^{\text {th }}$ grades. Reston, VA: National Association of Secondary School Principals.

48. Broda, H. (2002). Learning in and for the outdoors. Middle School Journal, 33 (3), 34-38.

49. Anderman, L.H., \& Midgley, C. (1997). Motivation and middle school students. In Judith L. Irvin (Ed.), What Current Research Says to the Middle Level Practitioner, 41-48.

50. Anderman, L.H., \& Midgley, C. (1997). Motivation and middle school students. In Judith L. Irvin (Ed.), What Current Research Says to the Middle Level Practitiioner, 41-48.

51. Lounsbury, J. \& Johnston, J. (1988) Life in the three $6^{\text {th }}$ grades. Reston, VA: National Association of Secondary School Principals.

52. Gaskill, P. (2002). Progress in the certification of middle level personnel. Middle School Journal, 33 (5), 33-40.

53. Gaskill, P. (2002). Progress in the certification of middle level personnel. Middle School Journal, 33 (5), 33-40.

54. Gaskill, P. (2002). Progress in the certification of middle level personnel. Middle School Journal, 33 (5), 33-40.

55. George, P., \& Alexander, M. (1993). The exemplary middle school. Fort Worth, TX: Harcourt College Publishers.

56. Williamson, R. \& Johnston, J. (1999, May). Serious answers to parent/public middle school concerns. The Education Digest, 64 (9), 4-11.

57. Beane, J. (1999). Middle schools under siege: Responding to points of attack. Middle School Journal, 30 (5), 3-12.

58. Anfara, V. \& Waks, L. (2000). Resolving the tension between academic rigor and developmental appropriateness. Middle School Journal, 32 (2), 46-51.

59. Beane, J. (1999). Middle schools under siege: responding to points of attack. Middle School Journal, 30 (5), 3-12. 
60. Lewis, A. (1996). Urban middle-grades reform: Foundations keep trying. The Harvard Education Letter, 7 (5), 5-6.

61. Bandlow, R. (2001). The misdirection of middle school reform: is a childcentered approach incompatible with achievement in math and science? The Clearing House, 75 (2), 69-73.

62. Norton, J. \& Lewis, A. (2000, June). Middle-grades reform. Phi Delta Kappan, 81 (10), K2-K4.

63. Callahan, C., Tomlinson, C., Reis, S., \& Kaplan, S. (2000). TIMSS and highability students - message of doom or opportunity for reflection. Phi Delta Kappan, 81 (10), 787-790.

64. Wheelock, A. (1996). Mathematics and science standards: What do they offer the middle grades? The Harvard Education Letter, 8 (5), 1-3.

65. Perlstein, Linda (2003). Not much just chillin’.

66. Beane, J. (1999). Middle schools under Siege: Responding to points of attack. Middle School Journal, 30 (5), 3-12.

67. Williamson, R. \& Johnston, J. (1999, May). Serious answers to parent/public middle school concerns. The Education Digest, 64 (9), 4-11.

68. Williamson, R. \& Johnston, J. (1999, May). Serious answers to parent/public middle school concerns. The Education Digest, 64 (9), 4-11.

69. Carper, J. \& Layman, J. Independent Christian day schools past, present, and prognosis. Journal of Research on Christian Education, 4 (1), 7-19.

70. Reichley, A.J. (1985). Religion in American public life. Washington, D.C.: The Brookings Institution.

71. Carper, J. \& Layman, J. Independent Christian day schools past, present, and prognosis. Journal of Research on Christian Education, 4 (1), 7-19.

72. Beane, J. (1999). Middle schools under siege: responding to points of attack. Middle School Journal, 30 (5), 3-12.

73. Edmund, D. (1999). Different rules for public and private Schools. Education Digest, 65 (3).

74. Carper, J. \& Layman, J. Independent Christian day schools past, present, and prognosis. Journal of Research on Christian Education, 4 (1), 7-19. 
75. Stover, D. (1999). Evolution controversy: The never-ending story. The Education Digest, 65 (3), 57-61.

76. Walley, C. \& Gerrick W.G. (1999). Affirming middle grades education. Boston, MA: Allyn and Bacon.

77. Roeser, R., Eccles, R., \& Sameroff, A. (2000). School as a context of early adolescents'academic and social-emotional development: A summary of research findings. Elementary School Journal, 100 (5), 443-471.

78. Issler, K. \& Habermas, R. (2002). How we learn a Christian teacher's guide to educational psychology. Eugene, OR: Resource Publications.

79. Walley, C. \& Gerrick W.G. (1999). Affirming middle grades education. Boston, MA: Allyn and Bacon. 


\section{BIBLIOGRAPHY}

Alegra, H., \& Sink, C. (2002). Another look at character education in Christian schools. Journal of Research on Christian Education, 11 (2), 161-181.

Anderman, E., Maehr, M., \& Midgley, C. (1999). Declining motivation after the transition to middle school: Schools can make a difference. Journal of Research and Development in Education, 32 (3), 131-145.

Anderman, L.H., \& Midgley, C. (1997). Motivation and middle school students. In Judith L. Irvin (Ed.), What Current Research Says to the Middle Level Practitiioner, 41-48.

Anfara, V. \& Waks, L. (2000). Resolving the tension between academic rigor and developmental appropriateness. Middle School Journal, 32 (2), 46-51.

Atwell, N. (1998). In the middle: New understanding about writing, reading, and learning. ( $2^{\text {nd }}$ ed.). Portsmouth, $\mathrm{NH}$ : Heinemann.

Bandlow, R. (2001). The misdirection of middle school reform: is a child-centered approach incompatible with achievement in math and science? The Clearing House, 75 (2), 69-73.

Beane, J. (1999). Middle schools under seige: Points of attack. Middle School Journal, 30 (4), 3-9

Beane, J. (1999). Middle schools under siege: Responding to points of attack. Middle School Journal, 30 (5), 3-12.

Berkowitz, J. \& Uline, C. A changing school culture: The case study of Galion Middle School. (1999). Columbus, OH: Ohio Department of Education.

Brockett, D. (1999). Re-examining MIDDLE-SCHOOL REFORM. The Education Digest, 64 (6), 30-33.

Broda, H. (2002). Learning in and for the outdoors. Middle School Journal, 33 (3), 3438.

Callahan, C., Tomlinson, C., Reis, S., \& Kaplan, S. (2000). TIMSS and high-ability students - Message of doom or opportunity for reflection. Phi Delta Kappan, 81 (10), 787-790.

Carnegie Council on Adolescent Development. (1989). Turning Points: Preparing American youth for the $21^{\text {st }}$ century. New York: Carnegie Corporation.

Carper, J. \& Layman, J. Independent Christian day schools past, present, and prognosis. 
Journal of Research on Christian Education, 4 (1), 7-19.

Classroom management and the middle school philosophy. (2002). Phi Delta Kappa Fastbacks, 500, 9-37.

Edmund, D. (1999). Different rules for public and private schools. Education Digest, 65 (3).

Elmore, R. (2000). Leadership for effective middle school practice. Phi Delta Kappan, 82 (4), 291-292.

Fibkins, W. (1998, May/June). How to handle a transition to a middle school model. Schools in the Middle, 7 (5), 13-14.

Frost, R., Olson, E., \& Valiquette, L. The wolf pack: Power shared and power earnedbuilding a middle school nation. Middle School Journal, 31 (5), 30-36.

Gaskill, P. (2002). Progress in the certification of middle level personnel. Middle School Journal, 33 (5), 33-40.

Gehlbach, H. \& Roeser, R. The middle way to motivating middle school students: avoiding false dichotomies. Middle School Journal, 33 (3), 39-46.

George, P. (1999). A middle school - If you can keep it: II. Midpoints Occasional Papers. National Middle School Association.

George, P., \& Alexander, M. (1993). The exemplary middle school. Fort Worth, TX: Harcourt College Publishers.

Hargreaves, A. \& Moore, S. (2000) Curricululm integration and classroom relevance: A study of teachers' practice. Journal of Curriculum and Supervision,15 (2), 89112 .

Issler, K. \& Habermas, R. (2002). How we learn a Christian teacher's guide to educational psychology. Eugene, OR: Resource Publications.

Kienel, P. (1998). A history of Christian school education. Colorado Springs, CO: The Association of Christian Schools International.

Knowles, T. \& Brown, D. (2000). What every middle school teacher should know. Portsmouth, NH: Heinemann NMSA.

Kohlberg, L. (1981). The philosophy of moral development: Moral stages and the idea of justice. San Francisco: Harper \& Row.

Lancaster, E. \& Rikard, G. (2002) Across the curriculum learning through movement. 
Middle School Journal, (33) 3, 28-33.

Lewis, A. (1996). Urban middle-grades reform: Foundations keep trying. The Harvard Education Letter, 7 (5), 5-6.

Lounsbury, J. \& Johnston, J. (1988) Life in the three $6^{\text {th }}$ grades. Reston, VA: National Association of Secondary School Principals.

Malloy, W. \& Rayle, J. (2000) Using the comer process to create a successful middle school. Middle School Journal, 31 (5), 12-18.

Norton, J. \& Lewis, A. (2000, June). Middle-grades reform. Phi Delta Kappan, 81 (10), K2-K4.

Oosterhuis, A. (2002). The development of a Christian ideology of inclusive education. Journal of Research on Christian Education. 11 (1), 5-31.

Perlstein, L. (2002). not much just chillin’. New York: Farrar, Straus and Giroux.

Reichley, A.J. (1985). Religion in American public life. Washington, D.C.: The Brookings Institution.

Roeser, R., Eccles, R., \& Sameroff, A. (2000). School as a context of early adolescents'academic and social-emotional development: A summary of research findings. Elementary School Journal, 100 (5), 443-471.

Schindler, C. (1987). Sowing for excellence. Whittier, CA: Association of Christian Schools International.

Schurr, S. (1992). How to evaluate your middle school. Columbus, OH: National Middle School Association.

Shoffner, M. \& Williamson, R. (2000). Facilitating student transitions into middle school. Middle School Journal, 31 (4), 47-51.

Slavin, R.E. (1986). Best-evidence synthesis: an alternative to meta-analytic and traditional reviews. Educational Researcher, 15, (9), 5-11.

Storz, M. \& Nestor, K. (2003). Insight into meeting standards from listening to the voices of urban students. Middle School Journal, 34 (4), 11-19.

Stover, D. (1999). Evolution controversy: The never-ending story. The Education Digest, 65 (3), 57-61.

Sutton, J., \& Watson, T. (1995). Barriers to excellence: A national survey of teachers from the American Association of Christian Schools. Journal of Research on 
Christian Education, 4 (1), 21-33.

Walley, C. \& Gerrick W.G. (1999). Affirming middle grades education. Boston, MA: Allyn and Bacon.

Weilbacher, G. (2000). Is curriculum integration an endangered species? Middle School Journal, 33(2) 18-27.

Wheelock, A. (1996). Mathematics and science standards: What do they offer the middle grades? The Harvard Education Letter, 8 (5), 1-3.

Williams, K. \& McGillicuddy-De Lisi, A. (2000) Coping strategies in adolescents. Journal of Applied Developmental Psychology, 20(4), 537-549.

Williamson, R. \& Johnston, J. (1999, May). Serious answers to parent/public middle school concerns. The Education Digest, 64 (9), 4-11.

Williamson, R. \& Johnston, J. (1999). Challenging Orthodoxy: An emerging agenda for middle level reform. Middle School Journal, 30 (4), 10-16. 
Teresea Baumann currently lives in Xenia, Ohio with her husband, Eddie, and her two children. Her oldest child, Abby, is fourteen and in eighth grade. Her youngest child, Jonathan, is twelve and in sixth grade. Abby and Jonathan both attend Xenia Christian which is part of the Dayton Christian school system. Teresea teaches sixth grade at Xenia Christian. She is an active member of Shawnee Hills Baptist Church where she is an Awana director for girls in grades 3-6. In her spare time, she enjoys traveling, running, reading, and relaxing. 